\title{
A Comparative Study between the Effect of Nerve Growth Factor and All-Trans Retinoic Acid versus their combined use on Taxol Induced Peripheral Neuropathy in Adult Male Albino Rat
}

Original

Article

\author{
Amany Abdelrahman ${ }^{1}$, Nesreen G. Abd Elhaliem ${ }^{2}$, Hassan M El-Nady ${ }^{3}$,Asmaa R. Lotfy, \\ Hoda M. Moghazy,
}

Departments of ${ }^{1}$ Physiology, ${ }^{2}$ Histology and ${ }^{3}$ Neurology, Faculty of Medicine, Sohag University

\begin{abstract}
Introduction: Peripheral neuropathy is a major side effect of chemotherapy. Nerve growth factor induces peripheral nerve regeneration. Retinoids play a significant role in neural growth.

Aim of the work: This study aimed to investigate the curative effect of either recombinant human nerve growth factor (rhNGF) or all trans-retinoic acid (ATRA) alone or together on taxol induced peripheral neuropathy.

Materials and methods: Fifty two male albino rats were divided into five groups. Group 1was control group. Group 2 was i.p. injected with taxol $(2 \mathrm{mg} / \mathrm{kg})$ on days 1, 3, 5, and 7. Group 3 received taxol as in group II then at the 10th day it was i.p. injected with NGF (10ug/kg daily for 20 days). Group 4 received taxol as in group II then at the 10th day it was i.p. injected with ATRA (25mgkg daily for 20 days). Group 5 received taxol as in group II then it was i.p. injected with rh-NGF and ATRA at the 10th day with the same previous dose. Neurophysiological assessment was done for sensory and motor nerve conduction velocity and amplitude as well as thermal pain threshold. Sections of sciatic nerve were prepared for immunohistochemichal and electron microscopic studies.

Results: Taxol injected animals exhibited signs of peripheral neuropathy at the 10th day after the first dose of taxol. There was a significant decrease in sensory and motor conduction as well as prolongation in thermal pain threshold. Myelinopathy (splitting, ovoid fragments and invagination) and axonapathy (compressed irregular axoplasm, myelin figures and destructed mitochondria) were seen in the histological examination. Glial fibrillary acidic protein immunoreactive positive cells were significantly increased. rh-NGF and ATRA could ameliorate the electrophysiological and the histological changes. Their combined use had the best result.

Conclusion: This study concluded that the use of rh-NGF and ATRA combination could improve taxol induced peripheral neuropathy in male albino rats.
\end{abstract}

Received: 22 January 2019, Accepted: 25 January 2019

Key Words: ATRA, GFAP, NGF, peripheral neuropathy, taxol, .

Corresponding Author: Nesreen G. Abd Elhaliem, MD, Histology Department, Faculty of Medicine, Sohag University, Sohag, Egypt, Tel.: +20 1006566743, E-mail: nesreengamal2000@yahoo.com

ISSN: 1110-0559, Vol. 42, No. 2

\section{INTRODUCTION}

Malignancy rate and use of cancer chemotherapy drugs is increasing. In 2012 about 14.1 million new cases of cancer occurred globally ${ }^{[1]}$. Peripheral neuropathy is a major side effect of chemotherapy; chemotherapy induced peripheral neuropathy (CIPN). In $50 \%$ of patients neuropathy is reported as irreversible ${ }^{[2]}$. Taxol is the most common commercial preparation for paclitaxel. It is effective in treatment of many types of malignancies yet, its neurotoxicity persist for long time after cessation of treatment ${ }^{[3]}$. The need for treatment of CIPN increased as the five year survival rates of many patients with cancer increased.

Paclitaxel (taxol) is a plant alkaloid ester derived from the bark of the western yew tree, Taxusbrevifolia. It is a mitotic inhibitor which exerts its action by formation of abnormal bundles of microtubules within the cytoplasm, leading to the disruption of normal cell function and proliferation. In patients, this results in the desired effect on the tumor, but this is accompanied by toxicity to normal tissue $^{[4]}$. Paclitaxel impair microtubule assembly as well as neuronal structure and function. In vitro studies have demonstrated that large abnormal microtubule arrays were formed in spinal cord-sensory ganglion following its exposure to paclitaxel, causing abnormal neurite outgrowth and neuronal death ${ }^{[5]}$.

Nerve growth factor (NGF) is a protein which is important for the growth, maintenance, and survival of certain target neurons. It was described as a member of the family "nerve growth factors" or neurotrophins which also include Brain-Derived Neurotrophic Factor and Neurotrophin- $3^{[6]}$. Therefore, it has therapeutic effect on topical treatment of corneal neurotropic ulcers and muscle healing after strain injury ${ }^{[7]}$. NGF is important for the survival and continuation of sympathetic and sensory neurons. Other studies showed that it can cause axonal growth, axonal branching and elongation ${ }^{[8]}$. 
Retinoids play a significant role in a variety of biological functions, particularly in epithelial and neural differentiation. They stimulate neurite outgrowth and promote functional regeneration in experimental peripheral nerve injury. Other studies demonstrated that all-trans retinoic acid (ATRA) administration reversed neuropathyassociated morphologic changes in animals ${ }^{[9]}$.

This study aimed to investigate and compare between the curative effect of ATRA, rhNGF, and their combination on peripheral neuropathy induced by taxol injection based on neurophysiological and histological studies.

\section{MATERIALS AND METHODS}

\subsection{Chemicals}

1. 1- Paclitaxel (Taxol) (Sigma Aldrich, St. Louis, MO) was diluted just before using in saline solution $0.9 \% \mathrm{Nacl}$ at a concentration of $1 \mathrm{mg} / \mathrm{ml}$.

2. 2- Recombinant human nerve growth factor (rh-NGF) (Sigma Aldrich, St. Louis, MO) was preserved at $-30{ }^{\circ} \mathrm{C}$ and then diluted just before using with saline $0.9 \%$ at a concentration of $10 \mathrm{ug} /$ $\mathrm{ml}$.

3. 3- All-trans retinoic acid (ATRA) (Sigma Aldrich, St. Louis, MO) was preserved and dissolved just before using in corn oil at a concentration of 20 $\mathrm{mg} / \mathrm{ml}$.

\subsection{Animals and experimental design}

Fifty two adult male albino Wister rats, 3 months old, (180- 200 gm) body weight, were obtained from animal facility, Sohag University. All animals were housed, divided and put into metal box cages in room at $22^{\circ} \mathrm{C}$ with good ventilation and normal light $\backslash$ dark cycle. They had open access to standard laboratory diet and tap water. The animals were adapted to diet and housing conditions for one week before starting of the experiment. The study was approved by Sohag Research Ethical Committee. They were randomized into 5 groups;

Group 1 (G1): they were subdivided into 4 subgroups

Group 1a (control group): 3 rats received daily intraperitoneal (i.p.) injection of physiological saline $1 \mathrm{ml} /$ $\mathrm{kg}$ on days $1,3,5$, and 7 then left up to the 10th day without treatment.

Group 1b (control group): 3 rats received daily i.p. injection of physiological saline $1 \mathrm{ml} / \mathrm{kg}$ on days $1,3,5$, and 7 then left up to the 30th day without treatment.

Rh NGF treated group G1c: 3 rats received daily i.p. injection of (10ug/kg) rhNGF for 20 days.

ATRA treated group G1d: 3 rats received daily i.p. injection of $(25 \mathrm{mg} / \mathrm{kg})$ retinoic A for 20 days.

Taxol treated group 2 (G2): 10 rats were i.p. injected with taxol $(2 \mathrm{mg} / \mathrm{kg})$ on days $1,3,5$, and 7 (10). This group was subdivided into
Group 2a: 5 rats left up to 10th day without treatment.

Group $2 b$ (recovery group): 5 rats left up to 30th day without treatment.

Taxol and rh NGF treated group 3 (G3): 10 rats were i.p. injected with taxol as in previous group II then at 10th of the study, they were daily i.p. injected with rh-NGF $(10 \mathrm{ug} / \mathrm{kg})$ for 20 days $^{[11]}$.

Taxol and ATRA treated group 4 (G4): 10 rats were injected taxol as in previous group II, then at the 10th day of the study, they were daily i.p. injected with ATRA $(25 \mathrm{mg} / \mathrm{kg})$ for 20 days $^{[12]}$.

Taxol and combined rh NGF and ATRA treated group 5 (G5): 10 rats were injected with taxol as in previous group II then at the 10th day of the study, they were daily i.p. injected with rh-NGF $(10 \mathrm{ug} / \mathrm{kg})$ and ATRA $(25 \mathrm{mg} / \mathrm{kg})$ for 20 days.

\subsection{Neurophysiological examination:}

Neurophysiological studies were done on days $1 \mathrm{st}$, 10th, 20th, and 30th from the start of the study.

\section{3.a. Nerve conduction studies}

The rats were narcotized by ketamine $100 \mathrm{mg} / \mathrm{kg}$, the sciatic nerve sensory and motor conduction studies were assessed using Neuropack 2 apparatus (NIHON KOHDEN MEM-7102K).

\section{3.a1. Caudal nerve sensory conduction study}

Sensory nerve conduction study of the caudal nerve was performed orthodromically by using two pairs of subcutaneous needle electrodes as the stimulating and recording electrodes. The reference recording electrode was placed at the base of the tail. The active recording electrode was placed $1 \mathrm{~cm}$ distal to the reference electrode. The cathode stimulating electrode was placed 3-4 cm distal to the active recording electrode the anode stimulating electrode, $1 \mathrm{~cm}$ distal to the cathode stimulating electrode. Negative peak latency and peak- to peak amplitude of the sensory nerve action potential (SNAP) were measured ${ }^{[13]}$. The distance between the stimulation and recording electrodes was measured in the straight tail position. The sensory nerve conduction velocity $(\mathrm{SNCV})=$ distance between stimulation and recording electrode/peak latency.

\section{3.a 2. Sciatic nerve motor conduction study}

Sciatic nerve motor conduction was assessed by examining the amplitude and latency of the evoked compound muscle action potentials (CMAPs) recorded from the feet. and paired needle stimulating electrodes inserted at the sciatic notch (hip; proximal) or the ankle (distal), the sciatic nerve was stimulated with supramaximal rectangular pulses of $0.05-\mathrm{ms}$ duration and the resulting CMAP was recorded from needle electrodes placed subcutaneously over the dorsal foot muscles. The compound motor conduction velocity $(\mathrm{MNCV})=$ distance between the 2 stimulation sites / difference between proximal and distal latencies ${ }^{[14]}$. 


\section{3.b. Hot Plate Test}

It was done for detection of thermal pain threshold on the rat tail. Rats were brought into the testing room and a period of acclimatization was provided. The surface of the hot plate was heated to a maximum temperature of $55^{\circ} \mathrm{C}$. Then the rat was placed in the testing apparatus and the timer is started. The latency to show a nociceptive response in form of tail withdrawal or hind paw jump was measured with the timer. The rat was immediately removed when this response is observed. 20 second cut-off time is considered with this protocol ${ }^{[15]}$.

\subsection{Histological examination}

The animals were anesthetized using $100 \mathrm{mg} / \mathrm{kg}$ of ketamin and dissected 24 hours after the last day of the experiment in each group. The proximal segments of sciatic nerve of the hind-limbs were taken and used for:

2.4.a. Immunohistochemical staining for glial fibrillary acidic protein (GFAP) using rabbit polyclonal anti-GFAP Ab-4 (was purchased from Thermo scientific Laboratories, Neomarks, Fremont, USA) for detection of Schwann cells. The specimens were fixed in $10 \%$ formalin for 24 hours then processed to obtain paraffin blocks by routine protocols. Sections of $4 \mu \mathrm{m}$ were prepared for immunostaining by the labeled streptavidin-biotin peroxidase complex technique (16). Negative control was used by omitting the primary antibody while cerebral cortex was used as positive control. The diluted concentration was 1:100 and the positive reaction was brown cytoplasmic coloration.

\section{4.b. Transmission electron microscope}

Small pieces of the sciatic nerve were fixed in $2.5 \%$ gluteraldhyde for 24 hours. The specimens were prepared to obtain semithin sections $(0.5-1 \mu \mathrm{m})$ by using Reichert super nova ultra microtome. The sections were stained with toluidine blue, examined by light microscope and photographed. Ultrathin sections (500-800 Ă) from selected areas of the trimmed block were made and collected on copper grids. They were stained by uranyl acetate for 10 min and lead citrate for 5 minutes then examined by Jeol TEM 1010 electron microscope in the EM unit of Sohag faculty of medicine ${ }^{[16]}$.

\section{4.c. Morphometric study}

The myelin sheath diameter and the axon diameter in transverse semithin sections of the sciatic nerve were measured in 10 different high power fields (X1000) from each slide in all groups. Then we estimated the g-ratio by dividing the diameter of the axon by the diameter of the myelin sheath of the nerve fiber ${ }^{[17]}$. The number of histopathological changes in sciatic nerves in semithin sections was counted in every 100 myelinated axons in high power fields (X1000) from each slide in all groups. The number of anti GFAP positive immunostained cells was counted in 10 different high power fields (X400) from each slide in all groups. All measurements of the previous parameters in the interested fields were done using microscopic photography unit, leica ICC Wetzlar (Germany) (Histology Department, Faculty of Medicine, Sohag University), and analysis of images was done by using Image J software (version 1.46r).

\subsection{Statistical analysis}

The collected data were statistically analyzed using Statistical Package Social Science (SPSS) (version 16.00; SPSS Inc., Chicago, Illinois, USA). Comparison between groups after the treatment was examined by using paired sample student t-test. Data were expressed as mean \pm standard error (SEM). $P<0.05$ was considered statistically significant.

\section{RESULTS}

\section{A. General observations}

There was no mortality in all groups during the experiment. However salivation, slight agitation and abnormal gait were noticed in $70 \%$ of rats in G2a and G2b.

\section{B. Neurophysiological results}

No significant differences in the sensory and motor nerve conduction velocities or amplitudes as well as thermal pain threshold between G1a, G1b, G1c and G1d were observed. There were insignificant differences in the 1 st day after administration of taxol in all groups.

\section{B. 1 Sensory nerve conduction studies:}

There was a significant decrease in the caudal nerve SCV and SNAP amplitudes in all treated groups 2, 3, 4 and 5 in comparison with control group $(p<0.05)$ at the 10 th day. However there was a significant $(p<0.05)$ increase in groups 3,4 and 5 at the 20 th and 30 th days in comparison with G2b. There was insignificant change between G3 and G4 at the 20th days while at the 30 th day while G3 showed a significant increase as compared to G4. G3 and G4 showed a significant decrease in comparison with G5 and control at the 30 th day. There was insignificant change in both velocity and amplitude in G5 in comparison with control G1 at the 30 th day (Tables 1 and 2) and (Histograms 1 and 2).

\section{B. 2 Motor nerve conduction studies of the sciatic nerve}

There was a significant decrease in sciatic nerve $\mathrm{MCV}$ and CMAP amplitude in groups 2,3,4 and 5 in comparison with group $1(p<0.05)$ at 10 th day. However there was gradual significant $(p<0.05)$ increase in G3, 4 and 5 at the $20^{\text {th }}$ and $30^{\text {th }}$ days in comparison with $\mathrm{G} 2 \mathrm{~b}$. There was insignificant change between G3 and G4 while both showed significant decrease in comparison with G5 at the $30^{\text {th }}$ day. There was insignificant change in both velocity and amplitude in G5 in comparison with control G1 at the $30^{\text {th }}$ day (Tables 3 and 4) and (Histograms 3 and 4).

\section{B. 3 Hot plate test}

There was a significant prolongation in the thermal pain threshold (hypoalgesia) as detected by the hot plate test in groups 2, 3, 4 and 5 as compared to the control group 
$(p<0.05)$ at $10^{\text {th }}$ and 20th day of the experiment. There was a significant $(p<0.05)$ reduction in the thermal threshold in both G3, 4 and 5 at the 20th and 30th days as compared to G2b while exhibited insignificant change as compared to the control group at the $30^{\text {th }}$ day. G3 showed a significant decrease as compared to $\mathrm{G} 4$ at the $20^{\text {th }}$ day. In spite of reduced threshold in G2b at the 30th day it still showed significant hypoalgesia (Table 5) and (Histogram 5).

\section{C. Histological and statistical results}

\section{C. 1. The histological examination}

The histological examination of G1a, G1b, G1c and G1d revealed the same structure of rat's sciatic nerve in semithin and immunostained sections. The examined semithin sections of the nerve fibers in group 1 showed scanty endoneurial connective tissue in between the densely packed fibers. The myelinated fibers showed regular myelin around the axon. The clusters of unmyelinated ones appeared as rounded or oval axons that enclosed by Schwann cell processes (Figure 1). The ultrastructure of control group nerve fibers myelin sheath appeared compact and uniform with node of Schmidt. Schwann cell wrapped around a single axon forming multilayer of myelin sheath (Figure 2a). Its cytoplasm contained euchromatic nucleus, rough endoplasmic reticulum (RER), mitochondria and primary lysosomes. The axoplasm of myelinated nerve fibers contained neurofilaments, microtubules and mitochondria. The unmyelinated nerve fibers were circular or ovoid in shape and grouped in cluster (Figure 2b). Examination of GFAP immunostaining sections revealed few positive Schwann cells of unmyelinated nerve axons and negative Schwann cells of myelinated ones (Figure 3).

The taxol treated G2a semithin sections exhibited variable histological changes in the myelin sheath as ballooning degeneration with complete splitting. There were numerous small diameter myelinated fibers while some large fibers had thin myelin sheath. The unmyelinated fibers were not affected (Figure 4). The ultrathin sections exhibited degenerative changes in axons and myelin sheath. There were membrane blebbing in the axolemma of degenerated fibers. Schwann cells cytoplasm had dilated RER and vacuoles (Figure 5a).The axoplasm of some myelinated fibers contained destructed mitochondria with complete loss of cristae in some. Myelin ovoid bubbles and complete splitting of myelin sheath with irregular compressed axon were frequently seen. The endoneurium contained bundles of collagen fibers (Figure 5b). Examination of GFAP immunostaining sections observed some positive Schwann cells of unmyelinated and myelinated nerve axons (Figure 6).

The semithin sections of the sciatic nerves of taxol recovery $\mathrm{G} 2 \mathrm{~b}$ showed numerous degenerated fibers, deformed myelin sheath in many fibers with noticeable invagination, evagination, fragmentation and separation of myelin sheath. There were numerous small axons (Figure 7). The ultrastructure of myelin sheath showed irregularity with complete splitting in some fibers. Fragmented ovoid myelin and ballooned destructed mitochondria appeared in the axoplasm of others. Irregular compressed axons were frequently seen. Schwann cells had euchromatic nuclei, dilated RER and vacuolated cytoplasm. The unmyelinated axons were of variable size and had intact mitochondria in their axoplasm (Figure 8). Examination of GFAP immunostaining sections showed many positive Schwann cells of myelinated nerve axons (Figure 9).

Taxol and rh-NGF treated G3 semithin sections revealed that some nerve fibers were more or less similar to the control group. However some fibers exhibited deformity in the form of separation and areas of invagination and evagination of myelin sheath and irregular small axons (Figure 10). The ultrathin sections of examined fibers revealed ballooning degeneration of myelin sheath and some deformed axons. Schwann cell had euchromatic nucleus with prominent nucleolus and vacuoles in the cytoplasm (Figure 11). Examination of GFAP immunostaining sections observed some positive Schwann cells of myelinated nerve axons (Figure 12).

Taxol and ATRA treated G4 semithin sections showed some nerve fibers were more or less similar to control while some had separation in myelin sheath and small irregular axons. There were numerous small diameter axons (Figure 13). The ultrastructure of myelin sheath of some fibers was dense with absence of node of Schmidt; also there were separation and splitting in the myelin sheath of some fibers. Unmyelinated axons were clustered in group (Figure 14). Examination of GFAP immunostaining sections observed few positive Schwann cells of myelinated nerve axons (Figure 15).

The examination of the combined rh-NGF and RA treated G5 semithin sections demonstrated that most of the nerve fibers were similar to control. Few fibers showed separation of myelin sheath, most nerve fibers were large in diameter (Figure 16). The ultrathin sections exhibited marked improvement in the previously mentioned degenerative changes. The nerve fibers were more or less similar to the control group. Fibers showed Schwann cell cytoplasm around the myelin sheath (Figure 17). Examination of GFAP immunostaining sections observed few positive Schwann cells of myelinated nerve axons (Figure 18).

\section{C.2. Morphometrical and statistical results}

In this study the diameter of the axon and myelin sheath of the myelinated nerve fibers of sciatic nerve were measured. In G2a and G2b the mean axon diameter and g-ratio were statistically significantly decreased as compared to G1. There was a significant increase In G3, G4 and G5 as compared to G2a and 2b. However there was a significant decrease in axon diameter and g-ratio in G3 and G4 in comparison with G5 and control group. G5 was statistically insignificant as compared to G1. As regard myelin sheath diameter there was a significant 
increase in G2a and b and G4 in comparison with control while G3 and G5 showed no significant difference. G4 exhibited a significant improvement in all these measures in comparison to G3 (Table 6) and (Histogram 6).

The mean number of the histopathological changes in sciatic nerves in group 2 ( $a$ and $b$ ) was significantly increased as compared to control group. As regard G4 and G5 there was significant decrease as compared to G2 (a and b) while there was insignificant change as compared to control group. However G3 still showed a significant increase in some histological changes as compared to control group, G4 and G5. (Table 7) and (Histogram 7)

GFAP immunostainnig sections of all treated groups showed insignificant change in the number of positive Schwann cells of unmyelinted fibers as compared to control. On the other hand in both taxol treated G2 ( $a$ and $b$ ) showed a significant increase in the number of immunopositive Schwann cells of myelinated fibers as compared to control group. However both G3 and G4 exhibited a significant decrease and increase as compared to $\mathrm{G} 2$ and $\mathrm{G} 5$ respectively. G5 showed insignificant change as compared to control (Table 7) and (Histogram 8).

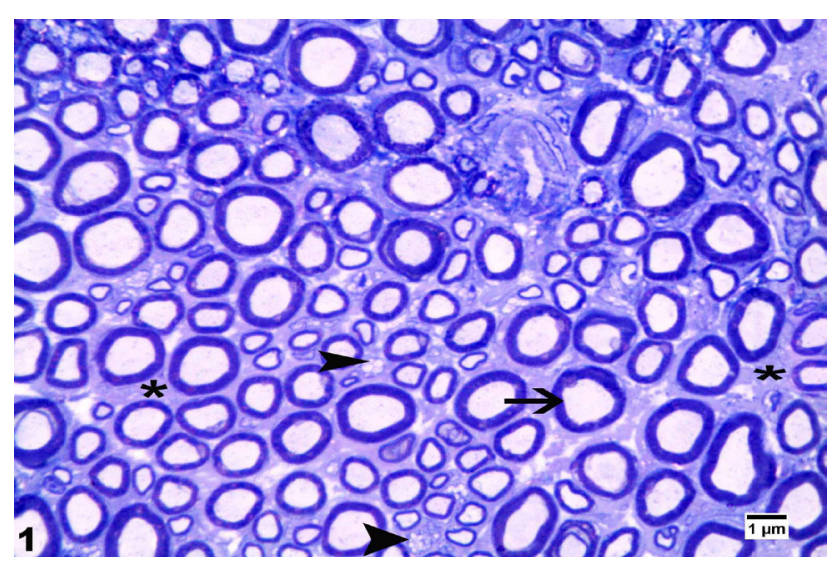

Fig. 1: A photomicrograph of a semithin section of sciatic nerve (G1) showing group of nerve fibers separated by endoneurial connective tissue (*). Myelinated nerve fibers (arrow) have regular myelin sheath with minimal infoldings. Note: unmyelinated nerve fibers (arrow head). Scale bar $1 \mu \mathrm{m} \quad$ (Toluidine blue X1000)

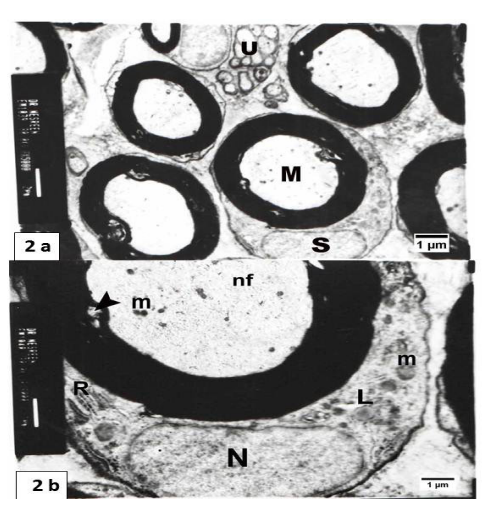

Fig. 2: An electron micrograph of sciatic nerve section of control group (G1) (2a) showing myelinated (M) and unmyelinated nerve fibers (u). Schwann cell (S) wraps around a single myelinated axon forming multilayer of myelin sheath. $(2 \mathrm{~b})$ showing a magnified part of myelinated nerve axon. Schwann cell wraps around single axon forming myelinated nerve axon. Schwann cell wraps around single axon forming
multilayer of myelin sheath. It contains euchromatic nucleus $(\mathrm{N})$, rough endoplasmic reticulum $(\mathrm{R})$, mitochondria $(\mathrm{m})$ and primary lysosomes (L). The axoplasm contains mitochondria $(\mathrm{m})$ and dense dots represent microtubules and neurofilaments (nf). Scale bar $1 \mu \mathrm{m}$ TEM (Uranyl acetate and lead citrate) (2a X5000, 2bX8000)

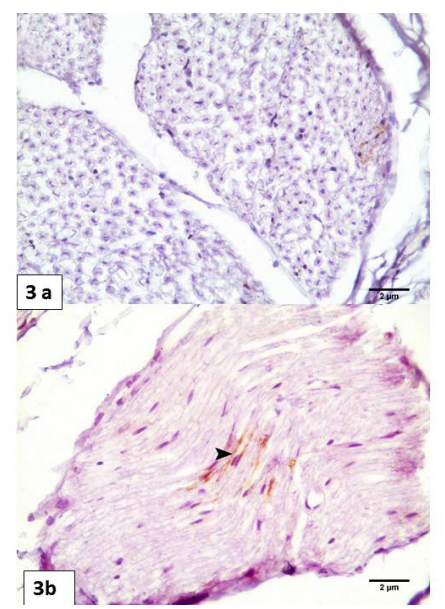

Fig. 3: A photomicrograph of a section of sciatic nerve (G1) (3a) showing negative reaction for anti GFAP immunostainning in Schwann cells of myelinated nerve axons and (3b) showing few positive Schwann cells of the unmyelinated nerve axons are seen (arrowhead). Scale bar $2 \mu \mathrm{m}$ GFAP antibody X400 


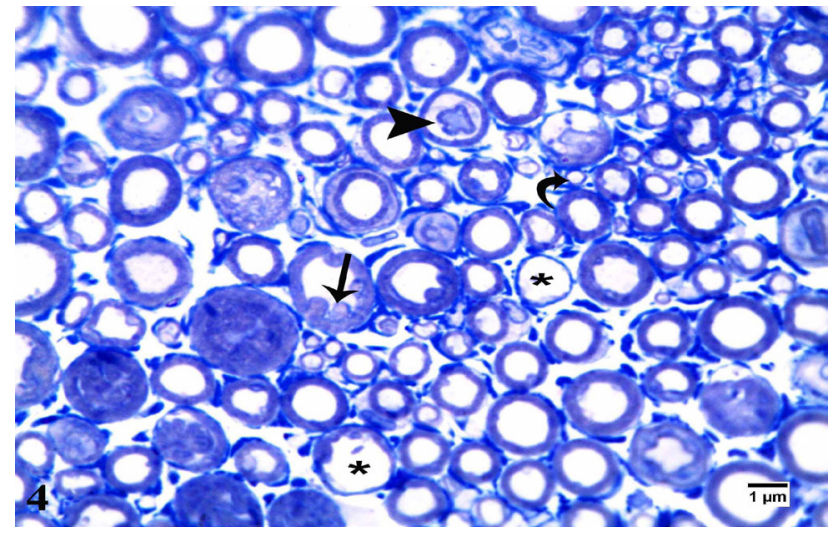

Fig. 4: A photomicrograph of a semithin section of sciatic nerve (G2a) showing degenerated myelinated fibers with formation of ovoid bubbles (arrow). Axonal separation is seen in some fibers (arrow head). There are numerous small diameter myelinated fibers (curved arrow) and scant endonurial tissue. Some large fibers have thin myelin sheath $(*)$. Scale bar $1 \mu \mathrm{m} \quad$ (Toluidine blue X1000)

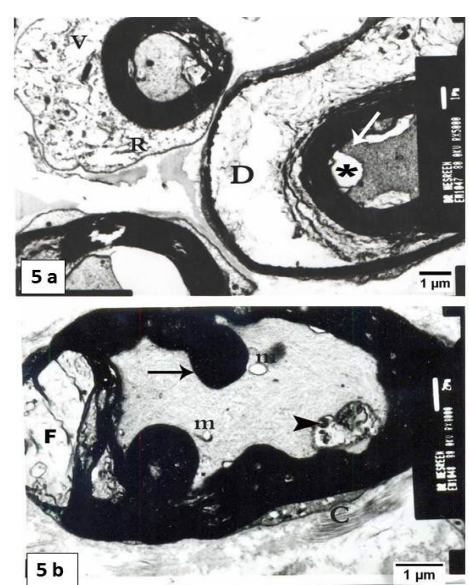

Fig. 5: An electron micrograph of sciatic nerve section of G2a (5a) showing ballooning degeneration (D) and complete splitting in myelin sheath with axon separation (*) and membrane blebbing (white arrow) Schwann cell cytoplasm has dilated RER (R) and vacuoles (V). (5b) showing irregular compressed axoplasm contains destructed mitochondria with loss of cristae (m) with appearance of myelin figure (arrowhead). Myelin ovoid bubbles (arrow) and focal area of splitting (F) are seen. Note: bundles of collagen fibers in the endoneurium (C). Scale bar $1 \mu \mathrm{m} \quad$ TEM (Uranyl acetate and lead citrate) (5a X5000, 5b X8000)

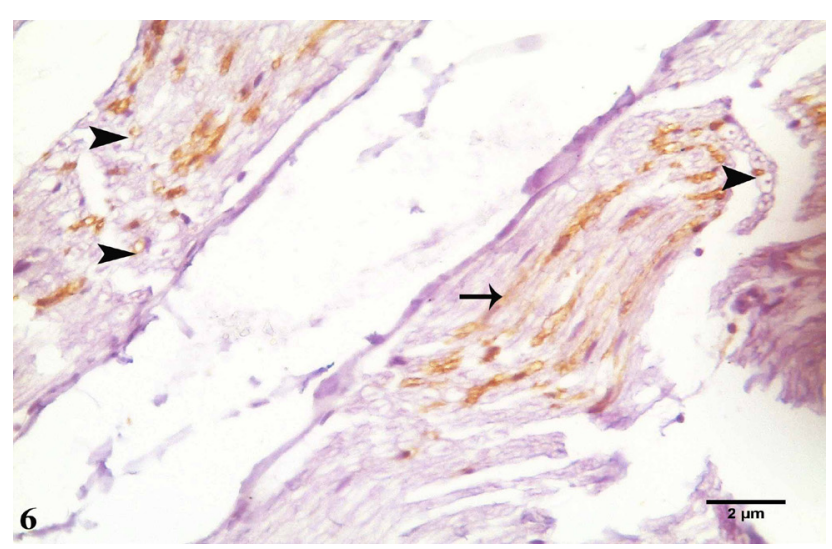

Fig. 6: A photomicrograph of a section of sciatic nerve (G2a) showing some positive anti GFAP immunostainning Schwann cells of non myelinated (arrow) and myelinated (arrowhead) nerve axons respectively. Scale bar $2 \mu \mathrm{m}$ GFAP antibody X400

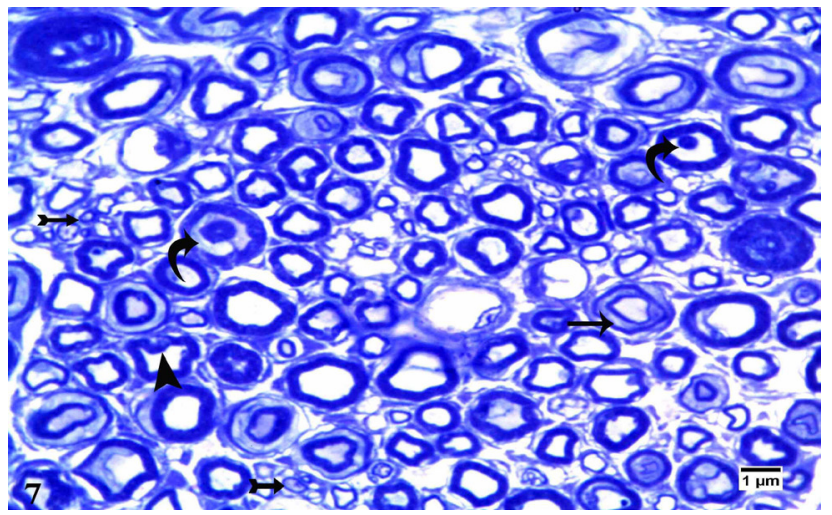

Fig. 7: A photomicrograph of a semithin section of sciatic nerve (G2b) showing numerous degenerated fibers and dispersed endonurium in between. Most fibers show deformed myelin sheath with area of invagination and evagination (arrow head). Others show ovoid fragmented myelin bubbles (curved arrow). Splitting of the myelin sheath (arrow) is frequently seen. Note: numerous small axons (tailed arrow). Scale bar $1 \mu \mathrm{m}$ (Toluidine blue X1000)

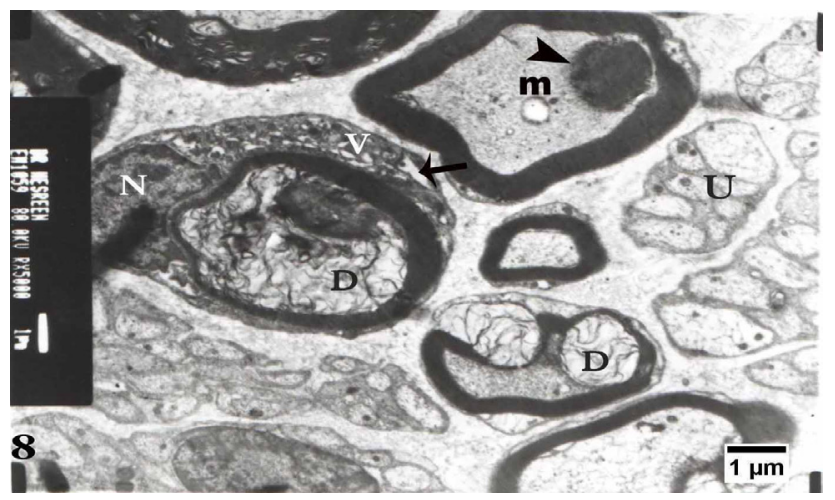

Fig. 8: An electron micrograph of sciatic nerve section of G2b showing fragmented ovoid myelin in the axoplasm (arrow head) and ballooned destructed mitochondria $(\mathrm{m})$. Some fibers have marked splitting of the myelin sheath in some areas (D) and small compressed axons. The clusters of intact unmyelinated axons of variable size (U). Note: Schwann cell with euchromatic nucleus (N), RER (arrow) and vacuoles in the cytoplasm (V). Scale bar $1 \mu \mathrm{m}$ TEM (Uranyl acetate and lead citrate X5000)

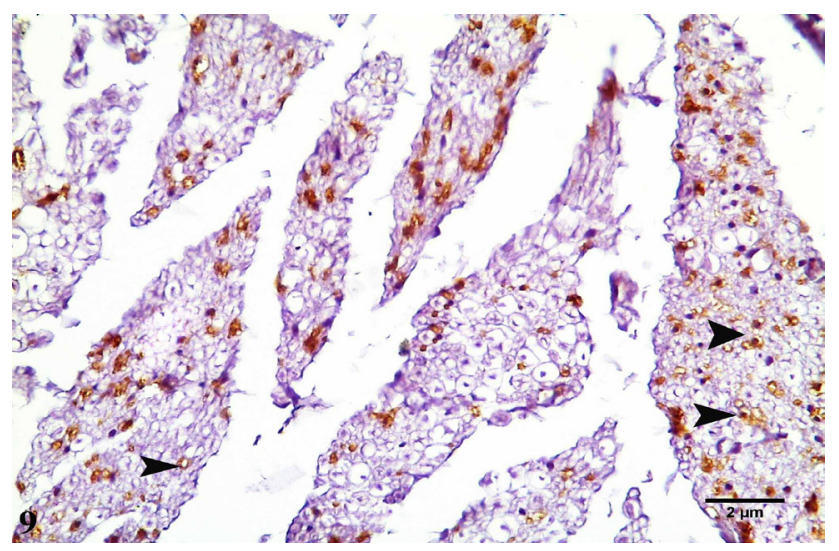

Fig. 9: A photomicrograph of a section of sciatic nerve (G2b) showing many positive anti GFAP immunostainning Schwann cells (arrowhead) of myelinated nerve axons. Scale bar $2 \mu \mathrm{m}$ antibody (X400) 


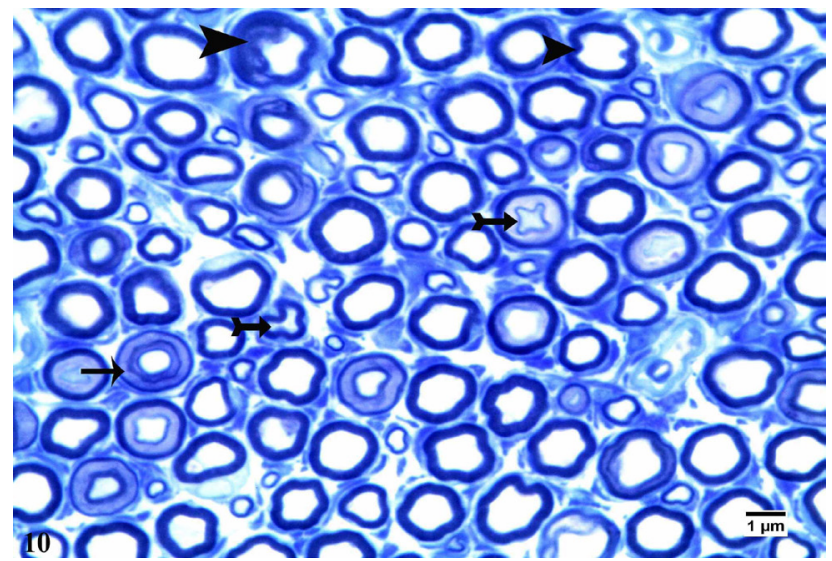

Fig. 10: A photomicrograph of a semithin section of sciatic nerve (G3) showing most of nerve fibers are similar to control group apart from some fibers have swollen separated myelin sheath (arrow). Others show irregular axons (tailed arrow). Few fibers have deformed myelin sheath with invagination and evagination (arrow head). Scale bar $1 \mu \mathrm{m}$ (Toluidine blue X1000)

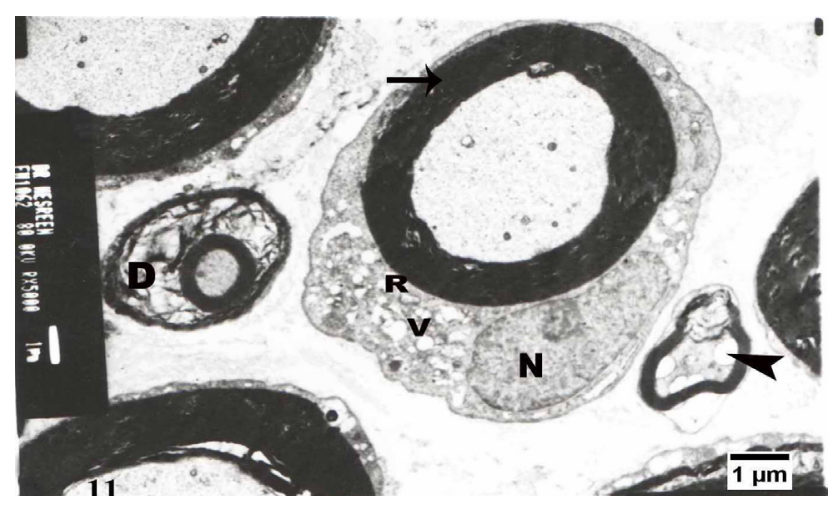

Fig. 11: An electron micrograph of sciatic nerve section of G3 showing some myelinated axons have myelin sheath more or less similar to control (arrow) while others show ballooning degeneration (D). Deformed separated axon (arrowhead) is also seen. Schwann cell has euchromatic nucleus with prominent nucleolus (N), dilated RER (R) and vacuoles (V). Scale bar $1 \mu \mathrm{m} \quad$ TEM (Uranyl acetate and lead citrate X5000)

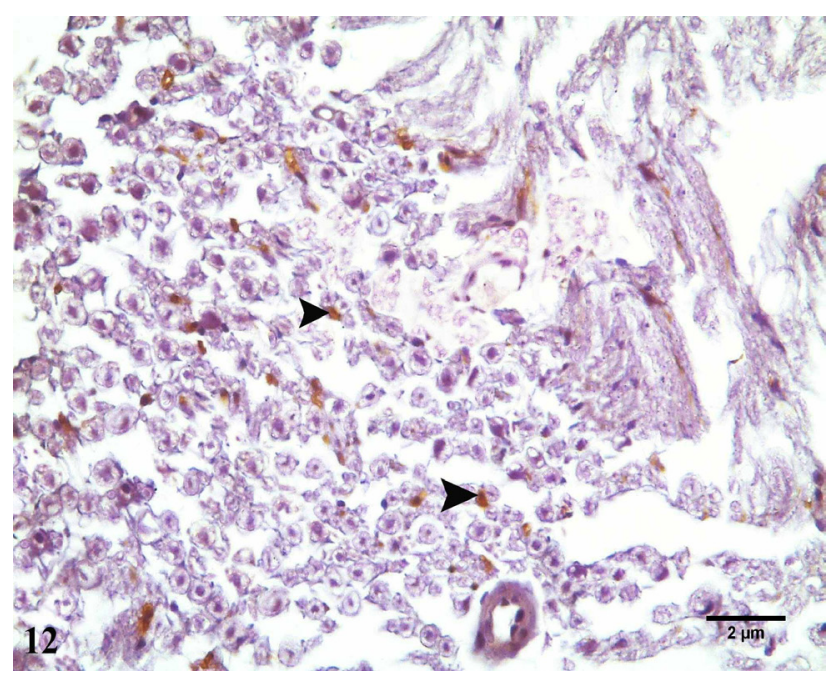

Fig. 12: A photomicrograph of a section of sciatic nerve (G3) showing some positive anti GFAP immunostainning Schwann cells (arrowhead) of myelinated nerve axons. Scale bar $2 \mu \mathrm{m}$ GFAP antibody (X400)

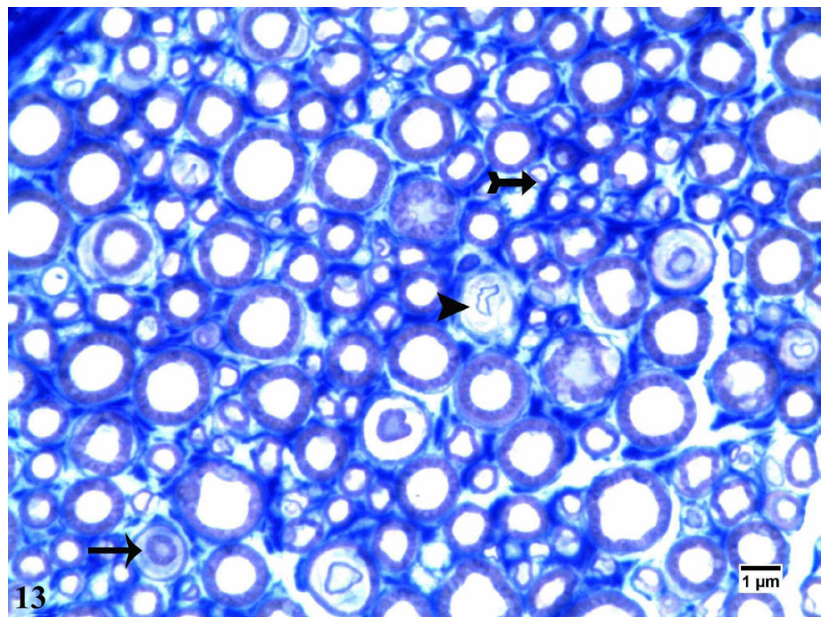

Fig. 13: A photomicrograph of a semithin section of sciatic nerve (G4) showing some nerve fibers are more or less similar to control group. Some fibers show separation of myelin sheath (arrow). Others show small irregular axon (arrow head). Note: numerous small diameter axons (tailed arrow). Scale bar $1 \mu \mathrm{m}$ (Toluidine blue X1000)

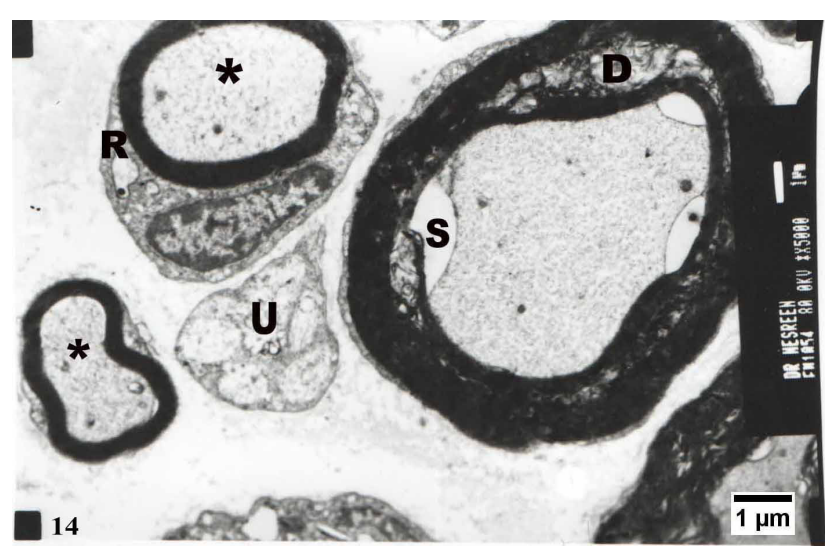

Fig. 14: An electron micrograph of sciatic nerve section of G4 showing some myelinated axons have dense myelin with absence of Node of Schmidt (*). Schwann cell cytoplasm contains euchromatic nucleus and dilated RER (R). Areas of axon separation (S) and splitting within the myelin sheath (D) are seen. Note: clusters of unmyelinated axons (U). Scale bar $1 \mu \mathrm{m}$ TEM (Uranyl acetate and lead citrate X5000)

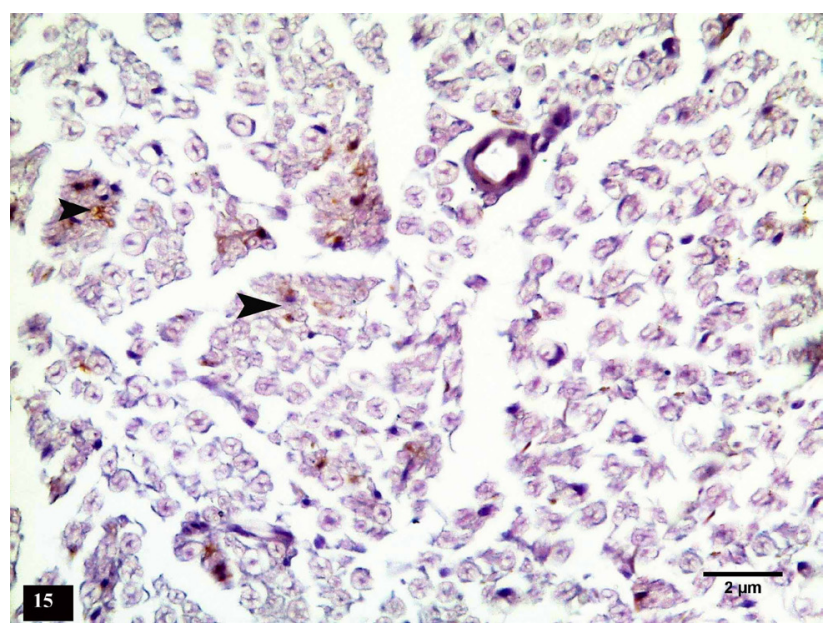

Fig. 15: A photomicrograph of a section of sciatic nerve (G4) showing few positive anti GFAP immunostainning Schwann cells (arrowhead) of myelinated nerve axons. Scale bar $2 \mu \mathrm{m}$ GFAP antibody (X400) 


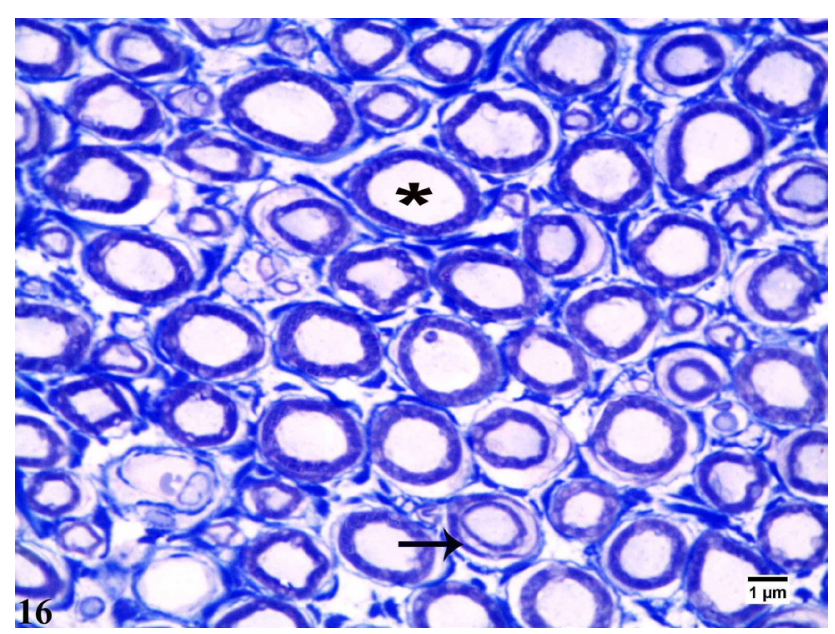

Fig. 16: A photomicrograph of a semithin section of sciatic nerve (G5) showing most of nerve fibers $(*)$ are more or less similar to control group. Few fibers show separation of myelin sheath (arrow). Scale bar $1 \mu \mathrm{m}$ (Toluidine blue X1000)

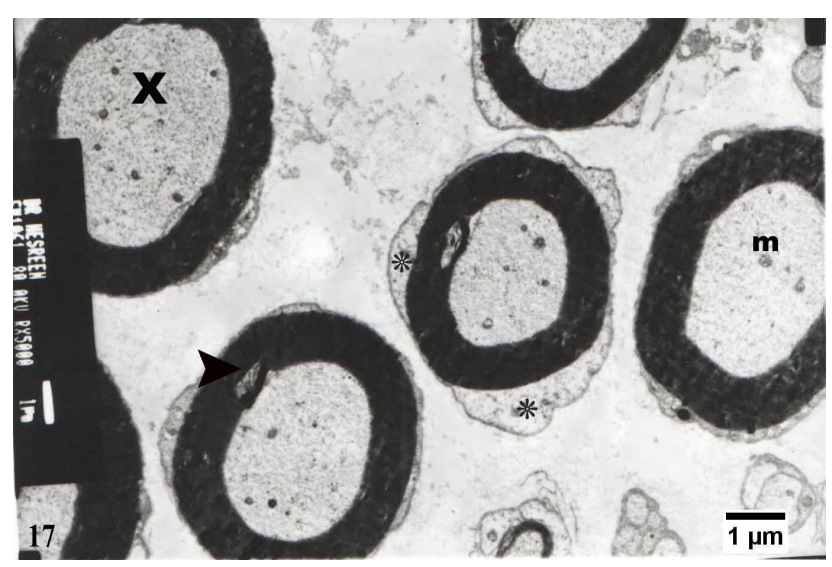

Fig. 17: An electron micrograph of sciatic nerve section of G5 showing most of axons are more or less similar to control group. Axoplasm contains intact mitochondria $(\mathrm{m})$ and numerous microtubules and neuroilaments $(\mathrm{X})$. Schwann cell cytoplasm is seen around the myelin sheath $(*)$. Note: node of Schmidt within myelin sheath (arrow head). Scale bar $1 \mu \mathrm{m}$ TEM (Uranyl acetate and lead citrate X5000)

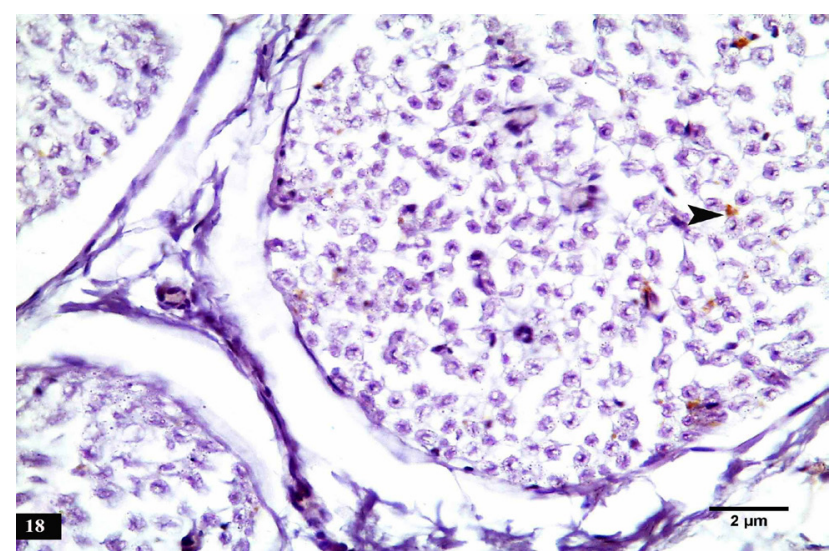

Fig. 18: A photomicrograph of a section of sciatic nerve (G5) showing few positive anti GFAP immunostainning Schwann cells (arrowhead) of myelinated nerve axons. Scale bar $2 \mu \mathrm{m} \quad$ GFAP antibody (X400)

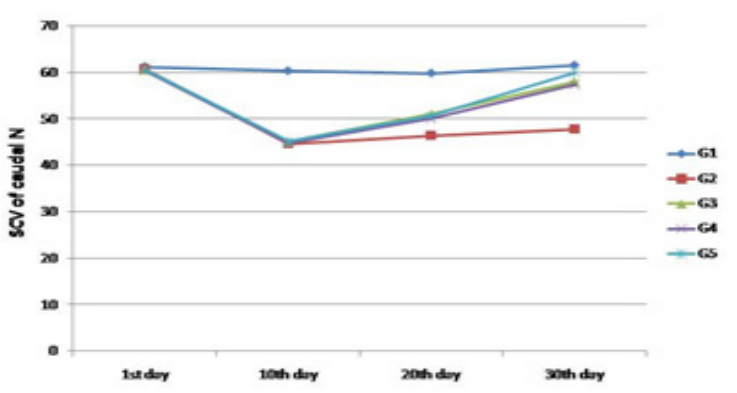

Histogram 1: The mean measurements of sensory nerve conduction velocity $(\mathrm{SNCV})$ of the caudal nerve at the $1^{\text {st }}, 10^{\text {th }}, 20^{\text {th }}$ and $30^{\text {th }}$ days in all groups

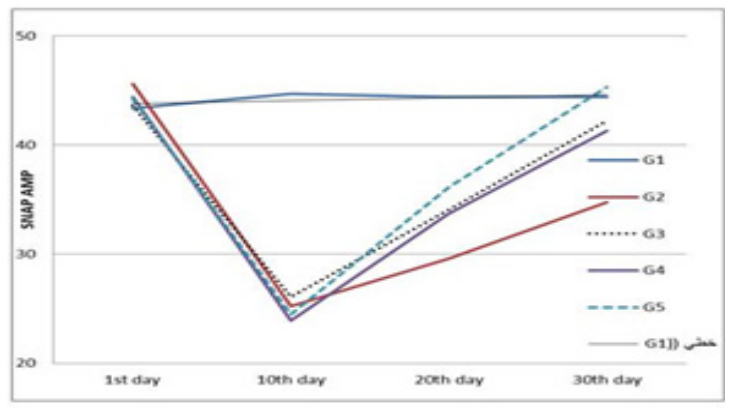

Histogram 2: The mean measurements of sensory nerve action potential amplitude (SNAP) of the caudal nerve at the $1^{\text {st }}, 10^{\text {th }}, 20^{\text {th }}$ and $30^{\text {th }}$ days in all groups

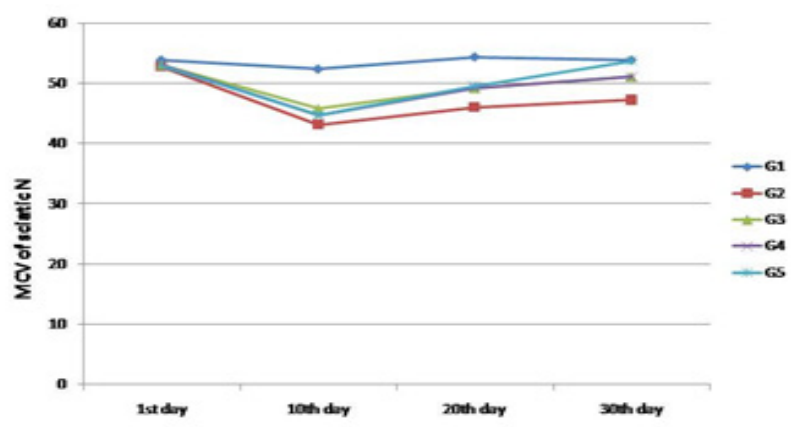

Histogram 3: The mean measurements of compound motor conduction velocity $(\mathrm{CMCV})$ of the sciatic nerve at the $1^{\text {st }}, 10^{\text {th }}, 20^{\text {th }}, 30^{\text {th }}$ days in all groups

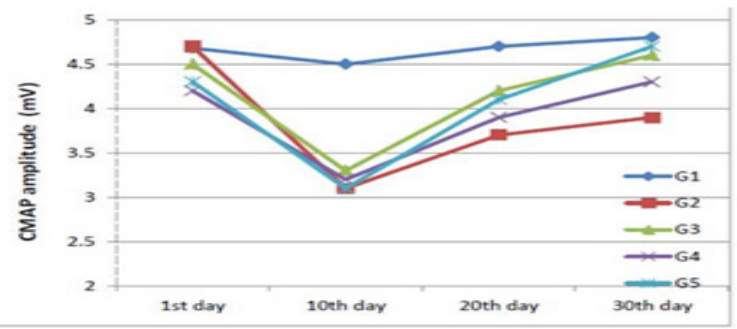

Histogram 4: Mean measurements of compound motor conduction action potential amplitude (SNAP) of the sciatic nerve at the $1^{\text {st }}, 10^{\text {th }}, 20^{\text {th }}$, $30^{\text {th }}$ days in all groups 


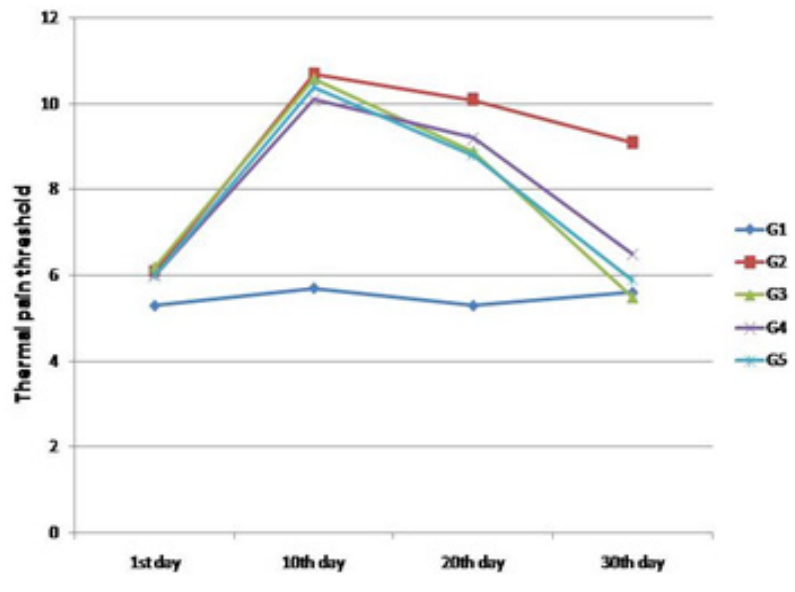

Histogram 5: The mean measurements of thermal pain threshold of the rat tail at the $1 \mathrm{st}, 10 \mathrm{th}, 20 \mathrm{th}, 30$ th days in all groups

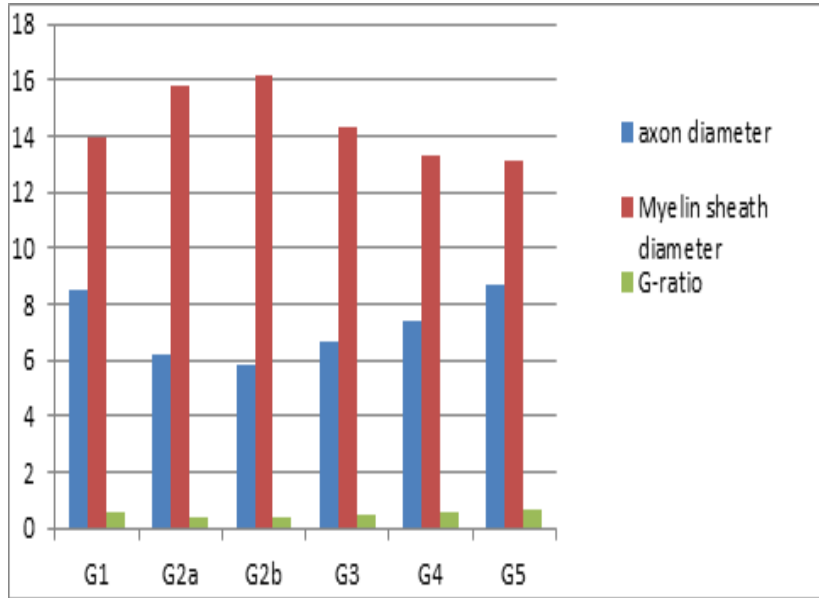

Histogram 6: The mean measurements of axon and myelin sheath diameters and g-ratio in all groups

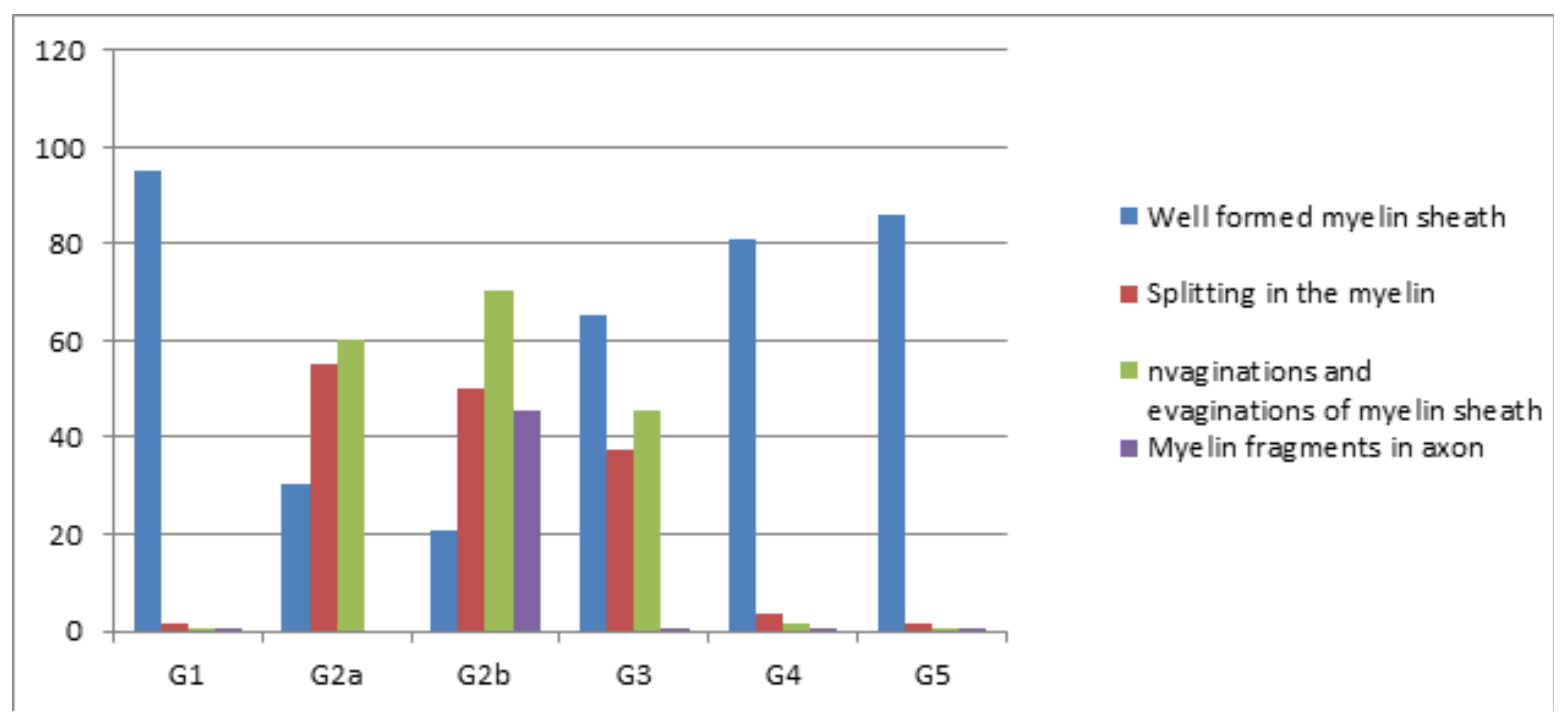

Histogram 7: the mean number of different histopathological changes of sciatic nerves in all groups.

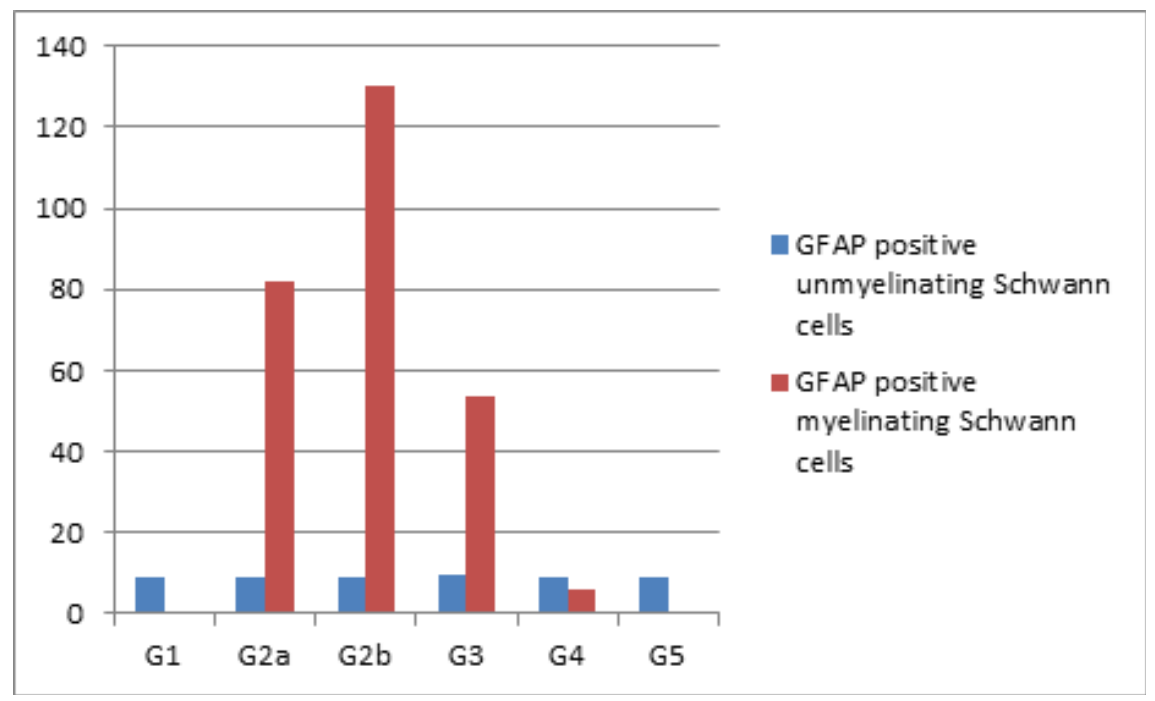

Histogram 8: The means number of GFAP positive Schwann cells in all groups 
Table 1: Mean \pm SD of the sensory conduction velocity of the caudal nerve (SCV) at $1^{\text {st }}, 10^{\text {th }}, 20^{\text {th }}$, and $30^{\text {th }}$ days after ${ }^{\text {st }}$ dose of taxol injection in all groups

\begin{tabular}{|c|c|c|c|c|c|c|}
\hline \multirow{2}{*}{ Caudal nerve SCV(m\s) } & \multirow{2}{*}{ G1 } & \multicolumn{2}{|c|}{ G2 } & \multirow{2}{*}{ G 3} & \multirow{2}{*}{ G4 } & \multirow{2}{*}{ G5 } \\
\hline & & G2a & $\mathrm{G} 2 \mathrm{~b}$ & & & \\
\hline $1^{\text {st }}$ day & $61.3 \pm 1.3$ & \multicolumn{2}{|c|}{$60.9 \pm 1.8$} & $60.7 \pm 2.3$ & $60.4 \pm 2.7$ & $60.7 \pm 2.4$ \\
\hline $10^{\text {th }}$ day & $60.4 \pm 3.2$ & \multicolumn{2}{|c|}{$44.7 \pm 3.7^{*}$} & $45.2 \pm 4.2^{*}$ & $44.8 \pm 3.2^{*}$ & $45.2 \pm 4.1^{*}$ \\
\hline $20^{\text {th }}$ day & $59.9 \pm 2.9$ & ---- & $46.5 \pm 4.5^{*}$ & $51.1 \pm 5.8^{*}$ & $50.1 \pm 6.4^{*}$ & $50.7 \pm 5.2^{*}$ \\
\hline $30^{\text {th }}$ day & $61.6 \pm 2.1$ & ---- & $47.9 \pm 5.1^{*}$ & $58.1 \pm 3.3^{* \#=+}$ & $57.4 \pm 4.2^{* \#=}$ & $60.1 \pm 3.7^{\#}$ \\
\hline
\end{tabular}

* significant at $P<0.05$ (compared to group 1), \# significant at $P<0.05$ (compared to group $2 \mathrm{a}$ and $\mathrm{b}$ ), $=$ significant at $P<0.05$ (compared to group 5), + significant at $P<0.05$ (compared to group 4) SD standard deviation

Table 2: Mean \pm SD of the sensory nerve action potential amplitude of the caudal nerve (SNAP amplitude in microvolt) at $1^{\text {st }}, 10^{\text {th }}, 20^{\text {th }}$, and $30^{\text {th }}$ days after $1^{\text {st }}$ dose of taxol injection

\begin{tabular}{|c|c|c|c|c|c|c|}
\hline \multirow{2}{*}{$\begin{array}{c}\text { Caudal nerve SNAP } \\
\text { amplitude }(\mu)\end{array}$} & \multirow{2}{*}{ G1 } & \multicolumn{2}{|c|}{ G2 } & \multirow{2}{*}{ G 3} & \multirow{2}{*}{ G4 } & \multirow{2}{*}{ G5 } \\
\hline & & G2a & $\mathrm{G} 2 \mathrm{~b}$ & & & \\
\hline $1^{\text {st }}$ day & $43.3 \pm 3.4$ & \multicolumn{2}{|c|}{$45.62 \pm 4.2$} & $43.6 \pm 3.9$ & $44.4 \pm 4.5$ & $44.22 \pm 4.1$ \\
\hline $10^{\text {th }}$ day & $44.8 \pm 4.1$ & \multicolumn{2}{|c|}{$25.2 \pm 6.1^{*}$} & $26.1 \pm 6.8^{*}$ & $23.9 \pm 5.5^{*}$ & $24.5 \pm 6.2^{*}$ \\
\hline $20^{\text {th }}$ day & $44.4 \pm 3.8$ & ---- & $29.6 \pm 4.6^{*}$ & $33.1 \pm 5.2^{\#^{*}}$ & $33.73 \pm 4.8^{\# *}$ & $34.12 \pm 5.2^{\# \prime}$ \\
\hline $30^{\text {th }}$ day & $44.4 \pm 3.9$ & ---- & $34.7 \pm 6.2^{*}$ & $42.2 \pm 4.4^{* \#=+}$ & $41.3 \pm 4.7^{* \#=}$ & $45.3 \pm 5.8^{\#}$ \\
\hline
\end{tabular}

* Significant at $P<0.05$ ( compared to group 1), \# significant at $P<0.05$ (compared to group $2 \mathrm{a}$ and $\mathrm{b}$ ), $=$ significant at $P<0.05$ (compared to group 5 ), + significant at $P<0.05$ (compared to group 4) SD standard deviation

Table 3: Mean \pm SD of the motor conduction velocity of the sciatic nerve (MCV) at $1^{\text {st }}, 10^{\text {th }}, 20^{\text {th }}$, and $30^{\text {th }}$ days after $1^{\text {st }}$ dose of taxol injection

\begin{tabular}{|c|c|c|c|c|c|c|}
\hline \multirow{2}{*}{ Sciatic MCV (m\s) } & \multirow{2}{*}{ G1 } & \multicolumn{2}{|c|}{ G2 } & \multirow{2}{*}{ G 3} & \multirow{2}{*}{ G4 } & \multirow{2}{*}{ G5 } \\
\hline & & G2a & $\mathrm{G} 2 \mathrm{~b}$ & & & \\
\hline $1^{\text {st }}$ day & $53.9 \pm 1.7$ & \multicolumn{2}{|c|}{$52.8 \pm 4.1$} & $53.1 \pm 2.5$ & $53.1 \pm 2.2$ & $52.9 \pm 2.5$ \\
\hline $10^{\text {th }}$ day & $52.4 \pm 1.6$ & \multicolumn{2}{|c|}{$43.2 \pm 2.7^{*}$} & $45.8 \pm 4.8^{*}$ & $44.7 \pm 3.7^{*}$ & $44.8 \pm 3.8^{*}$ \\
\hline $20^{\text {th }}$ day & $54.4 \pm 1.8$ & ---- & $46.1 \pm 4.3^{*}$ & $49.2 \pm 4.3^{* \#}$ & $49.2 \pm 4.3^{\text {*\# }}$ & $49.6 \pm 3.1^{* \#}$ \\
\hline $30^{\text {th }}$ day & $53.9 \pm 2.3$ & ---- & $47.3 \pm 4.4^{*}$ & $51.1 \pm 2.7^{* \#=}$ & $51.1 \pm 2.3^{* \#=}$ & $53.7 \pm 2.1^{\#}$ \\
\hline
\end{tabular}

* Significant at $P<0.05$ ( compared to group 1), \# significant at $P<0.05$ (compared to group $2 \mathrm{a}$ and $\mathrm{b}$ ), $=$ significant at $P<0.05$ (compared to group 5 ), + significant at $P<0.05$ (compared to group 4) SD standard deviation

Table 4: Mean $\pm \mathrm{SD}$ of the compound muscle action potential amplitude of the sciatic nerve (CMAP in microvolt) at $1^{\text {st }}, 10^{\text {th }}, 20^{\text {th }}$, and $30^{\text {th }}$ days after $1^{\text {st }}$ dose of taxol injection

\begin{tabular}{|c|c|c|c|c|c|c|}
\hline \multirow{2}{*}{$\begin{array}{l}\text { Sciatic nerve CMAP } \\
\text { amplitude (mv) }\end{array}$} & \multirow{2}{*}{ G1 } & \multicolumn{2}{|c|}{ G2 } & \multirow{2}{*}{ G 3} & \multirow{2}{*}{ G4 } & \multirow{2}{*}{ G5 } \\
\hline & & G2a & $\mathrm{G} 2 \mathrm{~b}$ & & & \\
\hline $1^{\text {st }}$ day & $4.6 \pm 0.7$ & \multicolumn{2}{|c|}{$4.7 \pm 0.6$} & $4.5 \pm 0.8$ & $4.2 \pm 0.7$ & $4.3 \pm 0.5$ \\
\hline $10^{\text {th }}$ day & $4.5 \pm 0.8$ & \multicolumn{2}{|c|}{$3.1 \pm 0.6^{*}$} & $3.3 \pm 0.5^{*}$ & $3.2 \pm 0.7^{*}$ & $3.1 \pm 0.3^{*}$ \\
\hline $20^{\text {th }}$ day & $4.7 \pm 0.4$ & ---- & $3.7 \pm 0.8^{*}$ & $4.2 \pm 0.7^{\# *}$ & $4.1 \pm 0.6^{\# *}$ & $4.2 \pm 0.4^{\# *}$ \\
\hline $30^{\text {th }}$ day & $4.8 \pm 0.4$ & ---- & $3.9 \pm 0.7^{*}$ & $4.4 \pm 0.5^{\#^{*}=}$ & $4.3 \pm 0.8^{\# *=}$ & $4.7 \pm 0.3^{\#}$ \\
\hline
\end{tabular}

* Significant at $P<0.05$ ( compared to group 1), \# significant at $P<0.05$ (compared to group 2a and b), significant at $P<0.05$ (compared to group 5), + significant at $P<0.05$ (compared to group 4) SD standard deviation

Table 5: Mean $\pm \mathrm{SD}$ of the thermal pain threshold results at $1^{\text {st }}, 10^{\text {th }}, 20^{\text {th }}, 30^{\text {th }}$ day after $1^{\text {st }}$ dose of taxol injection in all groups under the study

\begin{tabular}{|c|c|c|c|c|c|c|}
\hline \multirow{2}{*}{ Thermal pain threshold } & \multirow{2}{*}{ G1 } & \multicolumn{2}{|c|}{ G2 } & \multirow{2}{*}{ G 3} & \multirow{2}{*}{ G4 } & \multirow{2}{*}{ G5 } \\
\hline & & G2a & $\mathrm{G} 2 \mathrm{~b}$ & & & \\
\hline $1^{\text {st }}$ day & $5.3 \pm 0.9$ & \multicolumn{2}{|c|}{$5.7 \pm 0.9$} & $5.6 \pm 0.9$ & $5.8 \pm 0.6$ & $5.4 \pm 0.8$ \\
\hline $10^{\text {th }}$ day & $5.7 \pm 0.7$ & \multicolumn{2}{|c|}{$10.7 \pm 3.2^{*}$} & $10.6 \pm 3.4^{*}$ & $10.1 \pm 2.7^{*}$ & $10.4 \pm 2.9^{*}$ \\
\hline $20^{\text {th }}$ day & $5.3 \pm 0.9$ & ---- & $10.1 \pm 2.8^{*}$ & $8.9 \pm 2.5^{* \#+}$ & $9.2 \pm 2.1^{* \#=}$ & $8.8 \pm 2.4^{* \#}$ \\
\hline $30^{\text {th }}$ day & $5.4 \pm 0.6$ & ---- & $9.1 \pm 2.5^{*}$ & $5.5 \pm 1.1^{\#}$ & $5.7 \pm 1.2^{\#}$ & $5.4 \pm 0.8^{\#}$ \\
\hline
\end{tabular}

* Significant at $P<0.05$ ( compared to group 1), \# significant at $P<0.05$ (compared to group $2 \mathrm{a}$ and b), $=$ significant at $P<0.05$ (compared to group 5), + significant at $P<0.05$ (compared to group 4) SD standard deviation 
Table 6: Mean $\pm \mathrm{SD}$ of axon and myelin sheath diameter and g- ratio in different groups

\begin{tabular}{|c|c|c|c|c|c|c|}
\hline Parameter & G1 & G2a & $\mathrm{G} 2 \mathrm{~b}$ & G3 & G4 & G5 \\
\hline axon diameter $(\mu \mathrm{m})$ & $8.5 \pm 2.4$ & $6.2 \pm 2.3^{*}$ & $5.8 \pm 1.9^{*}$ & $6.7 \pm 2.5^{\# *=}$ & $7.4 \pm 3.1^{\# *_{*+}}$ & $8.7 \pm 3.5^{\#}$ \\
\hline Myelin sheath diameter $(\mu \mathrm{m})$ & $13.99 \pm 3.9$ & $15.84 \pm 1.8^{*}$ & $16.17 \pm 2.8^{*}$ & $14.29 \pm 3.2 * \#$ & $13.26 \pm 1.4^{\#+}$ & $13.11 \pm 3.5^{\#}$ \\
\hline G-ratio & $0.60 \pm 0.4$ & $0.41 \pm 0.2^{*}$ & $0.34 \pm 0.1^{*}$ & $0.51 \pm 0.3^{\# *=}$ & $0.53 \pm 0.25^{\#^{*}=+}$ & $0.62 \pm 0.6^{\#}$ \\
\hline
\end{tabular}

* significant at $P<0.05$ (compared to group 1), \# significant at $P<0.05$ (compared to group $2 \mathrm{a}$ and $\mathrm{b}$ ), $=$ significant at $P<0.05$ (compared to group 5 ), + significant at $P<0.05$ (compared to group 4) SD standard deviation

Table 7: Mean \pm SD of the number of different histopathological changes and GFAP positive Schwann cells of sciatic nerves in different groups

\begin{tabular}{|c|c|c|c|c|c|c|}
\hline Parameter & G1 & G2a & $\mathrm{G} 2 \mathrm{~b}$ & G3 & G4 & G5 \\
\hline Well formed myelin sheath & $95.3 \pm 1.1$ & $30.2 \pm 3.9^{*}$ & $20.8 \pm 2.5^{*}$ & $65.2 \pm 1.4^{\#=}$ & $80.8 \pm 3.2^{\#+}$ & $85.9 \pm 2.6^{\#}$ \\
\hline Splitting in the myelin & $1.6 \pm 2.3$ & $55.3 \pm 2.4^{*}$ & $50.2 \pm 2.9^{*}$ & $37.4 \pm 1.5^{* \#=}$ & $3.6 \pm 1.9^{\#+}$ & $1.3 \pm 2.8^{\#}$ \\
\hline Invaginations and evaginations of myelin sheath & $0.2 \pm 1.7$ & $60.4 \pm 3.6^{*}$ & $70.4 \pm 2.6^{*}$ & $45.7 \pm 1.6^{* \# \#}$ & $1.4 \pm 2.3^{\#+}$ & $0.3 \pm 1.2^{\#}$ \\
\hline Myelin fragments in axon & $0.1 \pm 1.3$ & $10 \pm 3.6^{*}$ & $63.4 \pm 2.3^{*}$ & $0.3 \pm 1.4^{\#}$ & $0.22 \pm 2.1^{\#}$ & $0.11 \pm 1.5^{\#}$ \\
\hline GFAP positive unmyelinating Schwann cells & $9.3 \pm 1.7$ & $8.99 \pm 2.5$ & $9.1 \pm 1.4$ & $9.4 \pm 2.1$ & $9.1 \pm 1.5$ & $8.89 \pm 1.9$ \\
\hline GFAP positive myelinating Schwann cells & $0.2 \pm 1.6$ & $82.12 \pm 2.3^{*}$ & $130.43 \pm 1.7^{*}$ & $53.92 \pm 1.5^{* \#}$ & $6.3 \pm 1.4^{* \#}$ & $0.3 \pm 2.1$ \\
\hline
\end{tabular}

* significant at $P<0.05$ (compared to group 1), \# significant at $P<0.05$ (compared to group $2 \mathrm{a}$ and $\mathrm{b}$ ), $=$ significant at $P<0.05$ (compared to group 5 ), + significant at $P<0.05$ (compared to group 4) SD standard deviation

\section{DISCUSSION}

This work had studied the therapeutic effect of rhNGF and ATRA on the neurotoxic effect of taxol on some electrophysiological functions of the caudal and sciatic nerves of the male albino rats and the histolopathological changes of the sciatic nerve. We found that i.p. injection of taxol in a dose of $2 \mathrm{mg} / \mathrm{kg}$ on days 1, 3, 5, 7 in cumulative dose $8 \mathrm{mg}$ could induced peripheral neuropathy 10 days after the first dose.

Taxol treated rats showed decreased sensory conduction velocities and amplitude of the caudal nerves about $26 \%$ and $45 \%$ respectively as well as decreased motor conduction velocities and amplitude of the sciatic nerve about $18 \%$ and $32 \%$ respectively. This might reflect the excess axonal loss and demyelinating lesions in the sensory neurons than the motor ones. In accordance with these findings it was reported that taxol tends to be highly concentrated in dorsal root ganglion neurons that lack blood nerve barrier which allowing its easy entrance to sensory rather than motor neurons ${ }^{[18]}$. This was in agreement with the previous study of Kawa (2014) who reported that rats exposed to paclitaxel injection showed decrease in motor and sensory $\mathrm{NCV}^{[20]}$. In contrast to our findings, previous in vitro studies found no changes on NCV after single large dose of taxol ${ }^{[19]}$. This discrepancy might be due to the low sensitivity of electrophysiological methods in early detection of neuropathy as the same researchers reported a decrease in $\mathrm{NCV}$ after prolonged treatment with taxol for 5 weeks. There was significant prolongation in thermal pain threshold compared to control rats (10.7 $\sec \pm 3.2$ versus $5.7 \mathrm{sec} \pm 0.7)$ in the present study. In agreement with our finding, Bardos et al. (2003) observed thermal hypoalgesia without morphological or electrophysiological changes ${ }^{[21]}$. However Polomano et al. (2001) described thermal hyperalgesia, mechanical allodynia and cold allodynia without any dose-response relationship ${ }^{[10]}$. However thermal hyperalgesia was commonly observed in rodent models of CIPN and thermal allodynia was also reported ${ }^{[22,9]}$. The inconsistent changes in pain threshold among different research groups might be due to the fact that current rodent models were not standardized for animal strain, age, sex, or drug dosing schedule ${ }^{[20]}$. The change in pain threshold might be interpreted by intraepidermal nerve fiber degeneration in taxol induced peripheral neuropathy ${ }^{[23]}$.

The synchronizing decrease in both sensory conduction velocity and amplitude could reflect simultaneous affection of neurons and Schwann cells after taxol treatment. The histopathological changes in sciatic nerve as thin myelin of large fibers, decrease size of axon diameter and significant decrease in the number of well formed myelin sheath were in accordance with the decrease in sensory conduction velocity. The atrophied separated axons might be secondary to reduction in the expression and transport of cytoskletal proteins especially myelin basic protein. This was in agreement with previous studies of paclitaxel and vincristine induced neuropathy which reported that these proteins maintain the structure of microfilaments of the axons which are important for its caliber ${ }^{[24]}$. On the other point of view, this decrease could be secondary to axon compression caused by myelin sheath edematous splitting or ballooning degeneration. There was subsequently decrease in g-ratio due to decrease the axon diameter with abnormal thickening of myelin sheath secondary to its splitting. This was explained the dysfunction in nerve impulse conduction in this study. The observed myelin bubbles suggested recurrent demyelination and remyelination of the axons. This could represent a continuous trial of Schwann cells that exhibited signs of cell activation as prominent nucleoli, dilated RER, vacuolated cytoplasm to produce myelin and 
improve the demyelinated axons ${ }^{[18]}$. Moreover the axons exhibited several changes as compression, membrane blebbing, destructed mitochondria and myelin figures. The myelin ovoid fragments in the axoplasm could reflect the Wallerian like degeneration in the axons ${ }^{[25]}$. These changes might be secondary to apoptotic changes in the neurons ${ }^{[26]}$. It was reported that taxol could induce apoptotic cell death by stabilizing the microtubules in the cells leading to mitosis arrest ${ }^{[27]}$. The microtubule stability affects axonal transport of growth factors necessary for axonal integrity ${ }^{[28]}$. Another mechanisms by which taxol could induce apoptotic effect is by stimulation of cytochrome $\mathrm{C}$ release which activates caspase signaling pathway or by binding to mitochondrial anti-apoptotic $\mathrm{Bcl} 2$ leading to its inactivation ${ }^{[29]}$. On the other hand, Kirchmair et al. (2005) found that CIPN induced because of damaged blood vessels of the nerves due to excess production of reactive oxygen species (ROS) ${ }^{[30]}$. In contrast to these findings some researchers found that this dose of taxol caused only endoneurial edema without any signs of axonal degeneration ${ }^{[10]}$.

Glial fibrillary acidic protein (GFAP) is a highly intermediate filament conserved protein expressed in differentiated glial cells as non myelinating Schwann cells $^{[31]}$. The myelinating Schwann cells acquire this protein in case of axonal neuropathy leading to its dedifferentiation and proliferation for axonal regrowth ${ }^{[32]}$. In this study the significant increase in the expression of GFAP-immunoreaction in myelinating Schwann cells in taxol group might be due to Wallerian like degeneration and separation of these cells from the axons secondary to myelin splitting. This led to increase the number of Schwann cells needed for axonal repair. Similarly, the previous studies reported that losing contact between Schwann cell and its axon led to loss of myelinating function and induce a cytoskeletal cellular change causing cytoplasmic accumulation of GFAP that lost during its development ${ }^{[33]}$. In accordance to this other studies found an increase in GFAP in the sciatic nerve after experimental nerve crush and triggered Schwann cells proliferation ${ }^{[34]}$.

In the present study the persistence of reduced SSNCV, $\mathrm{CMNCV}$ and the histopathological changes in recovery group might be due to slow rate of regeneration of the affected axons. It was proved that the regenerative process depends on the axoplasmic components flow that happens in a rate of $0.5-10 \mathrm{~mm} / \mathrm{day}^{[35]}$. These results were in agreement with Sahenk et al. (1994) ${ }^{[36]}$. However thermal pain threshold was improved but still showed upregulation as compared to control. This could be as a result to the absence of any morphological changes in the unmyelinated nerve fibers after taxol administration that facilitated the recovery of thermal hypoalgesia. These results was in accordance with the ability of taxol to induce lipid peroxidation so it attacked polyunsaturated fatty acids and concentrated in myelinated fibers away from the unmyelinated ones ${ }^{[37]}$.

Administration of rh-NGF in a dose of $(10 \mathrm{ug} / \mathrm{kg})$ in $\mathrm{G} 3$ revealed moderate improvement in SSNCV, CMNCV and amplitudes at $30^{\text {th }}$ day as compared to group treated with taxol alone. Moreover it caused significant increase in sensory conduction as compared to ATRA treated group. Similarly other works revealed that local or systemic administration of NGF produced long lasting allodynia, thermal and mechanical hyperalgesia ${ }^{[38]}$. These results were in accordance with Kehong et al. (2014) who found that rats treated with low and high doses of NGF faster sensory nerve conduction velocity in a cisplatin model of CIPN $^{[11]}$. However it was reported that NGF ameliorated sensory neuropathy while not prevent motor one in diabetic $\operatorname{rats}^{[39,40]}$

In this work the thermal pain threshold showed insignificant change after $30^{\text {th }}$ day in comparison with control group. This might be due to recovery from taxol as well as upregulation of neurotransmitters and sensitization of ion channels and receptors present on the afferent nerve fibers that are involved in nociception ${ }^{[41]}$. Previous studies found that NGF could increase the sensitivity of nociceptors indirectly by activating mast cells. Then, mast cells release pain mediators, including prostaglandins, bradykinin, histamine and NGF itself, which stimulates nociceptor terminals and improve the pain response ${ }^{[6]}$.

The good effect of NGF on the electrophysiological measurements was associated with mild improvement in histopathological changes. The significant decrease in the number of deformed axons as compared with taxol group could be due to its regulatory effect on the synthesis and stability of some cytoskeletal elements in neurons and its ability to reverse the toxic effect of taxol on microtubule assembly ${ }^{[42]}$. Moreover it also has antioxidant effect that overacts the ROS production by the upregulation of glutathione, catalase and glutathione peroxidase in sensory neurons ${ }^{[43]}$. There were some changes still observed as splitting of the myelin sheath and significant decrease in the mean axon diameter and g-ratio and significant increase in GFAP expression. This could be due to insufficient duration and /or dose of NGF to reverse these changes. In accordance to these findings it was reported that NGF could induce axonal extension and branching and protect against some of the toxic neuronal sensitivity changes without reversing the morphological changes ${ }^{[40]}$.

The administration of ATRA in a dose of $20 \mathrm{mg} \backslash \mathrm{kg}(\mathrm{G} 4)$ showed moderate improvement in SSNCV, CMNCV at $30^{\text {th }}$ day as compared to rats treated with taxol alone. These results were consistent with Arrieta et al. (2005) who found that ATRA reversed thermal pain threshold changes and increased nerve growth factor content in sciatic nerve and in serum in diabetic neuropathy ${ }^{[9]}$. The improvement in physiological parameters was associated with a significant decrease in the degenerative axonal changes as compared to taxol group. Morphometrical and statistical analysis showed a significant increase in the mean axon diameter and g-ratio of the sciatic nerve as compared to the taxol alone-treated group and G3 but still downregulated as compared to the control. The immunoexpresion of GFAP was reduced in comparison with taxol and G3 but not reach 
the control level as some nerve fibers exhibited deformed myelin. This might be secondary to neuroprotective effect of ATRA through stimulation and expression of their nuclear receptors ${ }^{[44]}$. The expression of these receptors plays an important role in regeneration of both sciatic nerve and Schwann cells. it was found that the regenerative ability of these receptors might be due to its stimulatory effect on Schwann cell migration that facilitates the remyelination of affected axons ${ }^{[45]}$. This migration is important for axonal elongation and regeneration by interacting with nerve fibers or basal lamina ${ }^{[46]}$. Furthermore it was found that retinoic A could stimulate axonal outgrowth and promotes functional regeneration of sensory axons in spinal cord ${ }^{[47]}$.

Combined therapeutic administration of NGF and ATRA (G5) showed insignificant change in SSNCV, $\mathrm{CMNCV}$ and thermal pain threshold as compared to control group. Moreover the mean axon diameter, g-ratio and the expression of GFAP were more or less similar to the control group. This might be due to the improved axonal histopathological changes and the quiescent state of Schwann cells as there was no need for their proliferation. This enhancement of the neurotherapeutic effect of this combination might be attributed to their synergistic action on taxol toxicity. ATRA is capable of regulating the expression of not only NGF but also other neurotrphopins, such as ciliary neurotrophic factor, neurotrophin-3, and brain-derived neurotrophic factor, which could participate in nerve regeneration ${ }^{[48]}$. It might also overlap the disability of NGF to improve the retraction or degeneration of sensory neurons by its effect on Schwann cells as previously mentioned $^{[40]}$. Moreover ATRA could regulate actin polymerization in microtubules that disturbed by taxol by transcription of the neurotrophin receptor genes ${ }^{[49]}$. On the other hand, NGF induces the production of retinaldehyde dehydrogenase type 2, which synthesizes retinoic acid and stimulates its intracellular pathways ${ }^{[50]}$.

This combination will be able to achieve the challenge in taxol chemotherapy as it could improve the induced neuropathy and increase the efficacy of its cytotoxicity. It was proved that beside their neuroprotective effect both ATRA and NGF was proved to have antitumor effect. Previous studies used ATRA either in the treatment of cancer as neuroblastoma and acute leukemia or as an adjuvant with other antiproliferative drugs ${ }^{[51]}$. It was also used as nanoparticles with paclitaxel for treatment of breast cancer in vivo and in vitro studies ${ }^{[52]}$ This was due to its specific effects on cell proliferation, differentiation, and apoptosis, as well as its low toxicity. On the other hand NGF could induce differentiation rather than proliferation in cancer cell line (pheochromocytoma, glioma, neuroblastoma and pancreatic beta cells ocular glioma ${ }^{[53]}$.

\section{CONCLUSION AND RECOMMENDATIONS}

It was concluded that that taxol could induce peripheral neuropathy at 10 th day after its $1^{\text {st }}$ dose that persisted up to $30^{\text {th }}$ day. It caused structural changes in myelinating Schwann cells as acquired cytoplasmic GFAP that was lost during its differentiation. This study found that the therapeutic use of NGF gave better results in improving the electrophysiological changes but not the histological ones as compared to ATRA. Their combined use was more effective to improve both changes than their use alone. We recommended the combined use of NGF and ATRA as a therapeutic approach for taxol induced peripheral neuropathy. Further studies must be done to prove their synergistic therapeutic effect in other regimens of taxol and to ensure that there is no interaction with its anti tumor efficacy.

\section{CONFLICT OF INTEREST}

The authors declare that they have no competing interests.

\section{ACKNOWLEDGMENT}

Hoda M Moghazy, designed the study research protocol, collect data, and share in the neurophysiological tests done for the animals. Nesreen G. Abdelhaliem designed the study and contributed to the histological and morphometrical studies. Amany Abdelrahman contributed to the nerve conduction studies made for the animals, designed the experiments, and wrote the manuscript. Hassan M Elnady contributed to neurophysiological tests for the animals, prepared the chemicals for the experiment, and analyzed data, and Asmaa R Lotfy shared in neurophysiological studies, collected and analyzed histological data. All authors read and approved the final paper.

\section{REFERENCES}

1. Organization WH. World Cancer Report. 2014;pp. Chapter 1.3.

2. Roxanne J. Wadia MS, Clarice Grens, Barbara E. Ehrlich and Herta, Chao H. The prevention of chemotherapy induced peripheral neuropathy by concurrent treatment with drugs used for bipolar disease: a retrospective chart analysis in human cancer patients. Oncotarget. 2017;9, (No. 7) PP: 7322-7331.

3. Zachary A Curry JLW, Deniz Bagdas, S Lauren Kyte, Nipa Patel, Giulia Donvito, Mohammed A Mustafa, Justin L Poklis, Micah J Niphakis, KuLung Hsu, Benjamin F Cravatt, David A Gewirtz, M Imad Damaj, Aron H Lichtman. Monoacylglycerol lipase inhibitors reverse paclitaxel-induced nociceptive behavior and proinflammatory markers in a mouse model of chemotherapyinduced neuropathy. JPET \#245704. 2018.

4. Grisold W, Cavaletti G, Windebank AJ. Peripheral neuropathies from chemotherapeutics and targeted agents: diagnosis, treatment, and prevention. Neuro-oncology. 2012;14 Suppl 4:iv45-54.

5. Chen H, Chan DC. Critical dependence of neurons on mitochondrial dynamics. Current opinion in cell biology. 2006;18(4):453-9. 
6. Eibl JK, Strasser BC, Ross GM. Structural, biological, and pharmacological strategies for the inhibition of nerve growth factor. Neurochemistry international. 2012;61(8):1266-75.

7. Ma K, Yan N, Huang Y, Cao G, Deng J, Deng Y. Effects of nerve growth factor on nerve regeneration after corneal nerve damage. International journal of clinical and experimental medicine. 2014;7(11):4584-9.

8. Zhao M, Li XY, Xu CY, Zou LP. Efficacy and safety of nerve growth factor for the treatment of neurological diseases: a meta-analysis of 64 randomized controlled trials involving 6,297 patients. Neural regeneration research. 2015;10(5):819-28.

9. Arrieta O, Garcia-Navarrete R, Zuniga S, Ordonez G, Ortiz A, Palencia G, et al. Retinoic acid increases tissue and plasma contents of nerve growth factor and prevents neuropathy in diabetic mice. European journal of clinical investigation. 2005;35(3):201-7.

10. Polomano RC, Mannes AJ, Clark US, Bennett GJ. A painful peripheral neuropathy in the rat produced by the chemotherapeutic drug, paclitaxel. Pain. 2001;94(3):293-304.

11. Kehong Bi NL, Haiyan Zhuang, Guosheng Jiang, Ge Wang. and Jinsong Gu. Pharmacodynamics of recombinant human nerve growth factor derivatives on peripheral neuropathy induced by cancer chemotherapy drugs. Journal of Chemical and Pharmaceutical Research, 2014; 6(11)544-549.

12. N. Hernandez-Pedro VG, Soto, G. Ordonez, B. Pineda, E. Rangel-Lopez, A.Salazar Ramiro, O. Arrieta, J. SoteloVitamin Vitamin A increases nerve growth factor and retinoic acid receptor beta and improves diabetic neuropathy in rats. Transl Res, 164 , pp 196-201. 2014.

13. Xia RH, Yosef N, Ubogu EE. Dorsal caudal tail and sciatic motor nerve conduction studies in adult mice: technical aspects and normative data. Muscle and nerve. 2010;41(6):850-6.

14. Jude M. Taylor PhD John D. Pollard MD P. Neurophysiological changes in demyelinating and axonal forms of acute experimental autoimmune neuritis in the Lewis rat. Muscle ,Nerve. Volume28, Issue3 Pages 344-3522003.

15. Allen JW, Yaksh TL. Assessment of acute thermal nociception in laboratory animals. Methods in molecular medicine. 2004;99:11-23.

16. Bancroft JD, Gamble M. Theory and practice of histological techniques. 6thed. Philadelphia: Churchill Livingstone, Elsevier; 2008. pp. $126,150,440$
17. Chomiak T, Hu B. What is the optimal value of the g-ratio for myelinated fibers in the rat CNS? A theoretical approach. PloS one. 2009;4(11):e7754.

18. Peters CM, Jimenez-Andrade JM, Kuskowski MA, Ghilardi JR, Mantyh PW. An evolving cellular pathology occurs in dorsal root ganglia, peripheral nerve and spinal cord following intravenous administration of paclitaxel in the rat. Brain research. 2007;1168:46-59.

19. Authier N, Balayssac D, Marchand F, Ling B, Zangarelli A, Descoeur J, et al. Animal models of chemotherapy-evoked painful peripheral neuropathies. Neurotherapeutics : the journal of the American Society for Experimental NeuroTherapeutics. 2009;6(4):620-9

20. Kawa FD, C.Y.Q. . Effects of Benfotiamine and Methylcobalamin on Paclitaxel Induced Peripheral Neuropathy $m$ iddle east journal of internal medicine 2014;2 (39).

21. Bardos G, Moricz K, Jaszlits L, Rabloczky G, Tory K, Racz I, et al. BGP-15, a hydroximic acid derivative, protects against cisplatin- or taxolinduced peripheral neuropathy in rats. Toxicology and applied pharmacology. 2003;190(1):9-16.

22. Zheng H, Xiao WH, Bennett GJ. Mitotoxicity and bortezomib-induced chronic painful peripheral neuropathy. Experimental neurology. 2012;238(2):225-34.

23. Xiao WH, Zheng $H$, Zheng FY, Nuydens $R$, Meert TF, Bennett GJ. Mitochondrial abnormality in sensory, but not motor, axons in paclitaxelevoked painful peripheral neuropathy in the rat. Neuroscience. 2011;199:461-9.

24. Boehmerle W, Huehnchen, P., Peruzzaro, S., Balkaya, M. and Endres, M. Electrophysiological, behavioral and histological characterization of paclitaxel, cisplatin, vincristine and bortezomibinduced neuropathy in $\mathrm{C} 57 \mathrm{Bl} / 6$ mice. Sci Rep 4: 63702014.

25. Gerdts J, Brace EJ, Sasaki Y, DiAntonio A, Milbrandt J. SARM1 activation triggers axon degeneration locally via $\mathrm{NAD}(+)$ destruction. Science. 2015;348(6233):453-7.

26. Mescher AL. Junqueira's basic histology Text and Atlas. 13th edition, McGraw Hill 2013; Chapter 3: P.69.

27. Yang, Chia-Ping, and Susan Horwitz. "Taxol $\AA$ : the first microtubule stabilizing agent." International journal of molecular sciences 18 , no. 8 (2017): 1733

28. Velasco R, Bruna J. Taxane-Induced Peripheral Neurotoxicity. Toxics. 2015;3(2):152-69. 
29. Canta A, Pozzi E, Carozzi VA. Mitochondrial Dysfunction in Chemotherapy-Induced Peripheral Neuropathy (CIPN). Toxics. 2015;3(2):198-223.

30. Kirchmair R, Walter DH, Ii M, Rittig K, Tietz $\mathrm{AB}$, Murayama $\mathrm{T}$, et al. Antiangiogenesis mediates cisplatin-induced peripheral neuropathy: attenuation or reversal by local vascular endothelial growth factor gene therapy without augmenting tumor growth. Circulation. 2005;111(20):2662-70.

31. Brenner M Kisseberth WC Su Y Besnard F Messing A GFAP promoter directs astrocytespecific expression in transgenic miceJ Neurosci 199414103037

32. Triolo, D., Dina, G., Lorenzetti, I., Malaguti, M., Morana, P., Del Carro, U., ... and Previtali, S. C. (2006). Loss of glial fibrillary acidic protein (GFAP) impairs Schwann cell proliferation and delays nerve regeneration after damage. Journal of cell science, 119(19), 3981-3993.

33. Bianchini, D., De Martini, I., Cadoni, A., Zicca, A., Tabaton, M., Schenone, A., ... and Mancardi, G. L. (1992). GFAP expression of human Schwann cells in tissue culture. Brain research, 570(1-2), 209-217.

34. Gugliandolo, E., D'amico, R., Cordaro, M., Fusco, R., Siracusa, R., Crupi, R., Impellizzeri, D., Cuzzocrea, S., ... Di Paola, R. (2018). Effect of PEA-OXA on neuropathic pain and functional recovery after sciatic nerve crush. Journal of neuroinflammation, 15(1), 264. doi:10.1186/ s12974-018-1303-5

35. Saladin KS PC. Nervous tissue. In: Kenneth S.Saladin (ed) Anatomy and physiology: the unity of form and function. WCB/McGraw-Hill co, New York pp 430-445 1998.

36. Sahenk Z, Barohn R, New P, Mendell JR. Taxol neuropathy. Electrodiagnostic and sural nerve biopsy findings. Archives of neurology. 1994;51(7):726-9.

37. Padmavathi R, Senthilnathan P, Chodon D, Sakthisekaran D. Therapeutic effect of paclitaxel and propolis on lipid peroxidation and antioxidant system in 7,12 dimethyl benz(a)anthraceneinduced breast cancer in female Sprague Dawley rats. Life sciences. 2006;78(24):2820-5.

38. Nakahashi Y, Kamiya Y, Funakoshi K, Miyazaki $\mathrm{T}$, Uchimoto $\mathrm{K}$, Tojo $\mathrm{K}$, et al. Role of nerve growth factor-tyrosine kinase receptor A signaling in paclitaxel-induced peripheral neuropathy in rats. Biochemical and biophysical research communications. 2014;444(3):415-9.

39. Apfel SC, Arezzo JC, Brownlee M, Federoff H, Kessler JA. Nerve growth factor administration protects against experimental diabetic sensory neuropathy. Brain research. 1994;634(1):7-12.

40. Pittman SK, Gracias NG, Fehrenbacher JC. Nerve growth factor alters microtubule targeting agentinduced neurotransmitter release but not MTAinduced neurite retraction in sensory neurons. Experimental neurology. 2016;279:104-15.

41. Park SB, Goldstein D, Krishnan AV, Lin CS, Friedlander ML, Cassidy J, et al. Chemotherapyinduced peripheral neurotoxicity: a critical analysis. CA: a cancer journal for clinicians. 2013;63(6):419-

42. Drubin DG, Feinstein SC, Shooter EM, Kirschner MW. Nerve growth factor-induced neurite outgrowth in PC12 cells involves the coordinate induction of microtubule assembly and assemblypromoting factors. The Journal of cell biology. 1985;101(5 Pt 1):1799-807.

43. Podratz JL, Windebank AJ. NGF rescues DRG neurons in vitro from oxidative damage produced by hemodialyzers. Neurotoxicology. 2005;26(3):343-50.

44. Hernandez-Pedro N, Granados-Soto V, Ordonez G, Pineda B, Rangel-Lopez E, Salazar-Ramiro A, et al. Vitamin A increases nerve growth factor and retinoic acid receptor beta and improves diabetic neuropathy in rats. Translational research : the journal of laboratory and clinical medicine. 2014;164(3):196-201.

45. Latasa MJ, Jimenez-Lara AM, Cosgaya JM. Retinoic acid regulates Schwann cell migration via NEDD9 induction by transcriptional and post-translational mechanisms. Biochimica et biophysica acta. 2016;1863(7 Pt A):1510-8.

46. Torigoe K, Tanaka HF, Takahashi A, Awaya A, Hashimoto K. Basic behavior of migratory Schwann cells in peripheral nerve regeneration. Experimental neurology. 1996;137(2):301-8.

47. Corcoran J, Maden M. Nerve growth factor acts via retinoic acid synthesis to stimulate neurite outgrowth. Nature neuroscience. 1999;2(4):307-8.

48. Baydas G, Reiter RJ, Nedzvetskii VS, Yasar A, Tuzcu M, Ozveren F, et al. Melatonin protects the central nervous system of rats against toluenecontaining thinner intoxication by reducing reactive gliosis. Toxicology letters. 2003;137(3):169-74.

49. Davies AM. Neurotrophins: more to NGF than just survival. Current Biology. 2000;10:R374-R376.

50. Palencia G, Hernandez-Pedro N, Saavedra-Perez D, Pena-Curiel O, Ortiz-Plata A, Ordonez G, et al. Retinoic acid reduces solvent-induced neuropathy and promotes neural regeneration in mice. Journal of neuroscience research. 2014;92(8):1062-70 
51. Schenk T, Stengel S, Zelent A. Unlocking the potential of retinoic acid in anticancer therapy. British journal of cancer. 2014;111(11):2039-45.

52. Huang H, Shi, H., Liu, J., Min, Y., Wang, Y., Wang, A. Z., ... and Liu, Y. Co-delivery of alltrans-retinoic acid enhances the anti-metastasis effect of albumin-bound paclitaxel nanoparticles. Chemical Communications. .2017;53(1), 212-215.

53. Aloe L, Rocco, M. L., Balzamino, B. O., and Micera, A. Nerve growth factor: role in growth, differentiation and controlling cancer cell development. Journal of Experimental and Clinical Cancer Research. 2016;35(1). 
الملخص العربى

\title{
دراسة مقارنة بين تأثير عامل نمو الأعصاب و حمض الريتينوك ضد استخدامهم

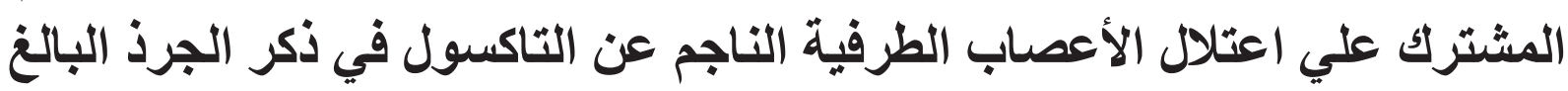

\author{
اماني عبد الرحمن'، نسرين جمال الدين عبد الحليمّ، \\ حسان محمد النادي"، اسماء رأفت لطقي' ، هدي مصطفي مغازي' \\ 'قسم الفسيولوجي، 'قسم الهستولوجي، "قسم العصبية ـ كلية الطب - جامعة سوهاج
}

المقدمة: يعد اعتلال الأعصاب الطرفية واحدا من أكثر الآثار الجانبية المزعجة لأدوية العلاج الكيميائي. ويعمل عامل نمو الأعصاب علي استعادة نمو الأعصاب بعد الإصابات. يلعب حمض الريتنينوك دورا هاما في مختلف الوظائف الحيوية خاصة نمو الأعصاب.تهدف هذه الدراسة لمقارنة التأثنير العلاجي لعامل نمو الأعصاب البشري وحمض الريتينوك أحدهما أو كلاهما معا علي اعتلال الأعصاب الطرفية الناجم عن العلاج الكيميائي بالتاكسول. المواد والأساليب : من الجرذان البيضاء الذكور البالغة قسمت إلي خمس مجموعات: المجموعة الأولى كانت

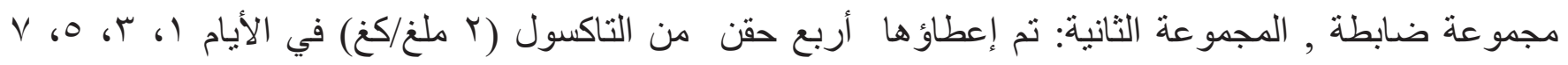
و المجموعة الثالثة : تم إعطاؤها التاكسول كما في السابق ثم من اليوم العاشر من التجربة تم الحقن البريتوني لعامل نمو الأعصاب (• (ميكروجر ام/كغ) يوميا ولمدة اسبو عين. المجموعة الرابعة : تم إعطاؤها التاكسول كما في السابق

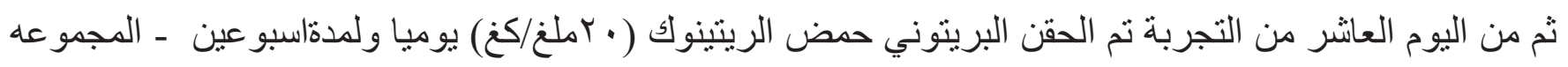
الخامسة: تم إعطاؤها التاكسول كما في السابق ثم من اليوم العاثر من التجربة الحقن البريتوني عامل نمو الأعصاب ( • (ميكروجر ام /كغ) وحمض الريتينوك (· (ملغ/كغ) معا يو مياولمدة اسبو عين. تم التقييم الفسيولوجي العصبي بقياس سر عة وسعة التوصيل الحسي والحركي و اختبار درجة احساس الألم الحر اري. جهزت قطاعات من العصب الوركي للار اسات الهستوكيميائية المناعية و الميكروسكوب الالكتروني. النتائج: تسبب التاكسول بظهور علامات اعتلال الأعصاب الطرفية في اليوم العاثر من أول جر عه له. وقد تبين بطء في سرعة التوصيل الحسي والحركي وزياده في الوقت اللازم للاحساس بالالم وكان ذلك ذو دلاله احصائية. اظهر الفحص النسيجي للعصب الوركي اعتلال مياليني (انفصال وشظايا بيضاوية واقلابات للاخل) و اعتلال في المحور العصبي (انضغاط و عدم انتظام للمحور العصبي و أشكال من الميلين و تكسر للميتوكوندريا). كما وجد زيادة في عدد الخلايا الايميونية الايجابية للبروتين الحمضي للألياف الدبقية ذو دلاله احصائية. ادي العلاج بعامل نمو الاعصاب اوحمض الريتينوك الي تحسن اعتلال الأعصاب الحسي و الحركي. تأثثير هم المشترك له أفضل النتائج في التغيرات الفسيولوجية العصبية و النسيجية المرضية. الاستتناج: هذه الدر اسة استتنجت ان الاستخدام المشترك لعامل نمو الاعصاب وحمض الريتينوك قد حسن التوصيل الحسي و الحركي والتركيب النسيجي للعصب في اعتلال الأعصاب الطرفية التاجم عن التاكسول. 